\title{
Kurumsallaşma ve Örgütsel Başarım Sürecinde İşletme Bilgi Sistemlerinin Etkinliğinin Sağlanmasında Muhasebe ve Denetim Fonksiyonlarının Rolü: Karaman OSB'de Bir Araştırma $^{1}$
}

\author{
The Role of Accounting and Auditing in Ensuring The Effectiveness of Business \\ Information Systems in The Process of Institutionalization and Organizational \\ Performance: A Research in Karaman Organized Industrial Zone
}

Evrim TARTAN SELÇUK

Namik Kemal ERDEMIR ${ }^{* *}$

\begin{abstract}
$\ddot{O} Z$
Sosyal ve ekonomik gelişmeler beraberinde birçok değişikliğe yol açmuştır. İhtiyaçlar hiyerarşisinde bahsedilen basamaklar aşıldıkça ihtiyaçlar çeşitlenmiş ve insanoğlunu sürekli yeniyi ve daha iyisini arar hale getirmiştir. Özellikle teknolojik değişimin baş döndüren ivmesi, konforu artırmış, mesafeleri kısaltmış, bilgiye ulaşım hızını artıırrken, erişim maliyetlerini azaltmış ve hayatın kolaylaştırılmasına aracılık etmiştir. Süreç, her alanda olduğu gibi iş yaşamında da köklü değişikliklere yol açmıştır. Bilgiye erişimin kolayliğı ve süreçlerin buna uygun şekilde dönüş̧türülmesinin yanında işletmelerde yerleşik geleneksel yönetim anlayışının sorgulanmasının önü açılmışıtır. Bilginin değerinin artışının yanında bilgiyi etkin kullanmanın öneminin anlaşllması rekabet açısından bilginin en önemli araç haline gelmesine sebep olmuştur. Bu nedenle bilgi sistemlerine verilen değer gittikçe artmış ve günümüzde en üst seviyesine ulaşmıştır.

Bu çalı̧̧mada yönetimin en önemli işlevlerinden biri olan karar alma süreçlerinde kullanılabilecek bilgi sistemlerinin rolü ele alınmıştır. Bu bilgi sistemlerinin içerisinde mali olayları kayıt altına almaktan daha önemli bir fonksiyonu olan muhasebe bilgi sistemi üzerinde durulmuștur. Küreselleşmenin sonucu olarak karar alıcıların doğru karar almalarına olumlu katk sağlayacak olan kurumsallaşma, raporlama sürecinin garantisi konumundaki denetim ve muhasebe bilgi sistemi iliş̧kileri incelenmişstir.Çalışmada çeşitli ölçeklerden faydalanılarak hazırlanan anket formu, Karaman OSB firmaları üzerine uygulanmıştır. ISşletmenin genel yönetim kararları ile Muhasebe Bilgi Sisteminin etkin kullanımı, kurumsallaşma düzeyi ile Muhasebe Bilgi Sisteminin etkin kullanımı ve kurumsallaşma düzeyi ile işletmelerdeki etkin denetim arasında anlamlı biri ilişki olup olmadığ araştırılmış ve anlamlı iliş̧kiler olduğu sonucuna varılmıştır.
\end{abstract}

ANAHTAR KELIMELER

Muhasebe Bilgi Sistemi, Kurumsallaşma, Denetim, Muhasebe, KARAMAN OSB

\begin{abstract}
The social and the economic progress has caused a lot of alterations. Human being has always searched for new and better things while the hierarchy of needs got more diverse. Especially with the dazzling acceleration in the technological changes, it has increased the comfort, shorten the distance, has increased the speed to reach information, moreover, has decreased the range costs and made life easier. The process has brought many revolution as on the work life. The convenience to reach knowledge and the process could now be more gross-examined in the firms. Beside the increase in the knowledge level, the effective use of the knowledge shows that it is important in many cases. This is why the value has increase more in the knowledge system and has become on the top stage nowadays.

In this study taking decision has been the most important the role in the knowledge system. In this knowledge system it has been focused on the accounting knowledge system which records the financial duties. In the study the questionnaire

\footnotetext{
${ }^{1}$ Bu araştırma, Karamanoğlu Mehmetbey Üniversitesi Bilimsel Araştırma Projeleri Komisyonunca kabul edilen 10-YL-16 nolu proje kapsamında desteklenmiștir. 18.01.2019 tarihinde KMU Sosyal Bilimler Enstitüsü tarafindan kabul edilen Yüksek Lisans Tezi özetidir.

* Doktora Öğrencisi, Karamanoğlu Mehmetbey Üniversitesi SBE, evrimtartan@kmu.edu.tr, ORCID: 0000-0002-4132-2765

${ }^{* * *}$ Dr. Öğr. Üyesi, Karamanoğlu Mehmetbey Üniversitesi IİBF İşletme, nkerdemir@kmu.edu.tr, ORCID: 0000-0003-1119-7833
} 
form prepared by using various scales from the literature and was applied on the OIZ firms in Karaman. It was investigated hether if there is a meaningful relationship between the general management decisions of the enterprise and the effective use of the Accounting Information System, the level of institutionalization and the effective use of the Accounting Information System and the level of institutionalization with the effective audit in the enterprises. It is concluded and that there are significant relationships.

\section{KEYWORDS}

Accounting Information System, Institutionalization, Audit, Accounting, KARAMAN OIZ

\begin{tabular}{|c|c|c|}
\hline \multicolumn{3}{|c|}{ Makale Geliş Tarihi / Submission Date } \\
O6.08.2020
\end{tabular}




\section{GİRIŞ}

İşletmelerin giderek çetinleşen rekabet ortamında varlıklarını sürdürme, karlılıklarını devam ettirme ve büyüme hedeflerine ulaşmalarının yolunun kurumsallaşmadan geçtiği bilinmektedir. Farklılaşmayı ve başarılı olmayı hedefleyen işletmelerin kurumsal bir yapıya kavuşmadan bu amaçlarına ulaşmaları mümkün değildir. Değişime açık, teknolojiyi takip eden, bilgi sistemlerini etkin kullanan, piyasa değeri yüksek, kreditörler ve paydaşlar nezdinde güvenilir bir imaja sahip bir işletme olmanın yolu da kurumsallaşmadan geçmektedir. Kurumsallaşmada en önemli araç ise bilgi olarak karşımıza çıkmaktadır.

Ekonomik, sosyal ve kültürel anlamda hızla değişen dünyamız, işletmeleri de değişime zorlamakta, artan rekabet koşulları işletmeleri fark yaratmak zorunda bırakmaktadır. Fark yaratmanın ve değişen dünyaya uyum sağlamanın zorunlu olduğu günümüzde işletmeler için bilginin değeri her geçen gün daha da önem kazanmaktadır. Teknolojinin hızla geliştiği, bireylerden kurumlara; devletlerden şirketlere kadar toplumun her kesiminin teknolojik olanaklardan yararlandığı bilgi çağında, işletmeler için de teknoloji, getirdiği kolaylıklarla birlikte, bir rekabet üstünlüğü de sağlamakta; teknolojiyi iyi kullanan işletmeler rakiplerinden farklılaşmaktadır.

Teknolojinin işletmeler için sağladığı en önemli avantajlardan biri işletmeye ihtiyaç duyduğu bilgiyi tam, doğru, zamanında ve ihtiyaç duyulan biçimde sağlaması; ayrıca üretilen bilgilerin muhafaza edilmesine olanak sağlayarak gereksinim duyulduğunda tekrar erişilmesine olanak sağlamasıdır.

İşletmeler için bilgi; karar alma süreçlerinde yol gösterici, gerçekçi hedefler belirlenmesine yardımcı işletmenin mevcut durumunu ortaya koyarken hedeflerine olan uzaklığını gösterici,müşteri analizine yardımcı, güçlü ve zayıf yanların tespiti ve kuruluştan bugüne aktarılarak işletmenin devamlılığını ve tutarlılığını sağlayıcı bir mekanizmadır.

Yönetim anlayışı da küreselleşme ve teknolojinin gelişimiyle birlikte gün geçtikçe değişmektedir. $\mathrm{Bu}$ değişim süreçleri yöneticileri de farklılaşmaya zorlayarak, teknolojiden en iyi şekilde yararlanmak isteyen, bilginin değerini kavramış ve elindeki bilgiyi doğru kullanabilen bir yönetici tarzını yaratmıştır. Günümüzde gerçek liderler de gücünü, bilgiden ve bilgiyi yönetme gücünden almakta, yönetim bilgi sistemlerinin etkinliği liderin başarısında kilit rol oynamaktadır.

Yönetim bilgi sistemi işletme yönetimine ihtiyaç duyduğu bilgileri sağlayan sistemler bütünüdür. İşletmenin stratejik kararlarını etkileyen, planlama yapmasına olanak sağlayan bilgiler yönetim bilgi sistemlerinden elde edilir. Yönetim işletmenin hedeflerini belirler; bu hedeflere ulaşılması sürecinde yapılan faaliyetleri planlar, örgütler, koordinasyonu sağlar ve her aşamada kontrol eder. Tüm bu süreçlerde yönetimin en önemli fonksiyonu karar vermedir.

Yönetimin temel işlevi, amaçlara ulaşılmasını sağlamaktır. Bunun için etkin kararlar alınmalı ve alınan kararların yerine getirilmesi sağlanmalıdır. Bundan dolayı karar mekanizmasının olmadığı ya da işlevsiz olduğu bir yönetim düşünülemez. Bu bakımdan yönetim, yapısal olarak insanlar ve onlara ilişkin eylemler, işleyiş mekanizması yönünden ise karar alma süreciyle ilgilidir (Yozgat, 1994,6)

Yöneticiler, işletmenin amaçlarına ulaşmasını sağlamaya çalışırken çeşitli bilgi sistemlerinden faydalanırlar. Bu bilgi sistemlerinin sağlıklı çalışması ve birbiri ile koordineli olması son derece önemlidir. Muhasebe bilgi sistemi (MBS), işletme içerisindeki diğer bilgi sistemlerinin birbiri ile iletişimini sağlayan, karar alıcıların daha sağlıklı bir süreç yürütmelerine imkân tanıyan bir niteliktedir. MBS başarının sayısallaştırılarak ölçülmesine, geleceğe yönelik tahminler yapılmasına olanak sağlar. MBS'nin kendinden beklenilen faydaları sağlayabilmesi ise bu süreçte üretilen verilerin doğruluğunun sağlanması ve garanti altında olması ile mümkündür. Bu noktada ise denetim fonksiyonu önem kazanmaktadır.

Kısaca, kurumsallaşmanın firmaların başarısında son derece önemli olduğu, kurumsallaşmadan beklenilen faydaların sağlanmasında ise denetimden geçerek güvence altına alınmış muhasebe bilgilerinin hayati rol oynadığını ifade etmek mümkündür.

\section{KAVRAMSAL ÇERÇEVE}

\subsection{Kurumsallaşma}

Kullanımda birbirinin yerine kullanılmakla birlikte kurumsallaşma ve kurumsal yönetim farklı iki kavram olarak karşımıza çıkmaktadır.

Kurumsallaşma; işletmenin içinde bulunduğu piyasa şartlarına ve çağın gerekliliklerine uyum sağlayacak biçimde yönetilmesi ve organizasyon yapılarını oluşturmas1, buna uygun sistemler yaratması, kendine ait davranış, standart, kural ve prensipler belirlemesi, bunları kalıcı hale getirerek uygulayabilmesi sürecidir (Aydemir vd., 2004,606). Kurumsallaşma, işletmeleri sadece mal ve hizmet üreten birim olmaktan çıkarıp duygular ve geleneklerle yönlendirilen kurumlar haline getirmektedir (Ulukan, 2005, 89). Kurumsal yönetim 
ile şeffaf ve hesap verebilir bir yönetim anlayışının yanında işletme ile ilgili tüm tarafların menfaatlerini adil bir şekilde gözeten, sosyal sorumluluk bilincini benimsemiş ilke ve kurallar bütününün anlaşılması gerekir. (Eminoğlu, 2014: 9). Kurumsal yönetim sayesinde şirketin yönetim kurulu, ortakları ve diğer menfaat sahipleri yani paydaşları arasındaki ilişkiler sağlıklı bir hale gelmektedir (Aktaş, 2017,2).

Kurumsallaşma ve kurumsal yönetimin 4 sac ayağının (şeffaflık, hesap verebilirlik, sosyal sorumluluk, adillik) ortak olması nedeniyle kurumsallaşmış bir yapıda kurumsal yönetim ilkelerinin uygulanması nispeten daha basittir. Kurumsal yönetim ilkeleri ilgili taraflarla olan ilişki, rol ve sorumlulukları belli yapı ve davranış kurallarına göre yürütüleceğinden kurumsallaşma bu durumdan olumlu olarak etkilenecektir. (Alp ve Kılıç, 2014: 29). Bu süreçlerin nihai hedefi işletmenin piyasa değerini yükseltmek, açık bir yönetim anlayışıyla işletmenin tüm ilgililerinin haklarını korumaktır.

Kurumsallaşma firmaların itibarlarının artmasını sağlamaktadır. Yüksek itibar sayesinde firmalar rekabet avantaj1 elde etmektedirler (Başok Yurdakul, 2008, 65). Standart hale getirilmiş süreçler işletmeye istikrar kazandırırken, çalışanların kendini güvende hissetmesini sağlayacak, bu durum çalışanların işletmeye olan aidiyetini dolayısıyla verimliliğini artıracaktır. Müşterilerde sadakat, tedarikçilerde güven duygusu hızla artacaktır. Ayrıca yatırımcılar firmaya olan güvenleri nedeniyle yatırım yapmaya daha istekli hale gelecektir (Erdil vd., 2002, 193). Kurumsal bir yönetim ile işletmeler, sosyal sorumluluk bilinciyle, şeffaf, adil ve hesap verebilir bir konumda olacaktır. Kurumsal yönetim bu dört ilke doğrultusunda, işletme ilgililerine karar alırken kullanabilecekleri bilgilerin, zamanında, doğru, eksiksiz, anlaşılabilir, yorumlanabilir, düşük maliyetle kolay erişilebilir bir şekilde duyurabilecektir. Bilgilendirme temelde mali tablolar ile yapılmaktadır.

\subsection{Muhasebe ve Denetim Fonksiyonlarının Kurumsallaşmadaki Rolü}

Kurumsal yönetimin benimsenmesi ile elde edilen sonuçların değerlendirilebilmesi ve analizlerin yapılabilmesi için MBS tarafından üretilen mali tablolara ihtiyaç duyulmaktadır. İşletmelerden doğru ve güvenilir muhasebe kayıtları yanında işletme ile ilgili taraflara gereksinim duydukları bilgileri sorumluluk anlayışı ile anlaşılır biçimde şeffaf, hesap verebilirlik yaklaşımı ile zamanında sunmaları istenmektedir (Dızman ve Güney, 2015, 48). Mali tablolardaki bilgiler, hem işletme yönetiminin etkinliğinin anlaşılmasına hem de kurumsal yönetim ilkelerinin uygulanmasının yarattı̆̆ sonuçların ölçülmesine olanak sağlayan araçlar olarak değerlendirilebilir. Bu anlamda MBS ve kurumsal yönetim uygulamaları etkin bir yönetimin sağlanması için birlikte çalışan karşılıklı ve bütünlüklü iki güç olarak nitelendirilebilir (Abdioğlu ve Dinç, 2009, 158). MBS'nin etkinliği işletmelerin ihtiyaç duydukları bilgilere ulaşmalarının yanında kurumsal yönetim ilkelerinin içselleştirilmesini ve ilkelerin doğru biçimde uygulanmalarını da sağlar. MBS kurumsal yönetim uygulamalarının temeli, teminatı ve tamamlayıcısıdır (Kaderli ve Köroğlu, 2014, 22).

MBS ve kurumsal yönetim birbirinden ayrı düşünülemez. MBS bir yandan kurumsal yönetimin şeffaflık ilkesi gereği açıklayacağı bilgileri oluşturur, sorumluluk ilkesinin gereği olan denetimin gerçekleşmesine olanak verir, hesap verebilirlik ilkesinin bir gereği olarak yönetimin performansının ölçülmesini sağlar. Muhasebenin temel ilkeleri ile kurumsal yönetimin temel anlayışları ve amaçları ortaktır ve ikisi de yönetimin etkinliğinin sağlanmasına olanak verir. Kurumsal yönetim anlayışının ortaya çıkıp benimsenmesi ile muhasebenin yalnızca vergi amaçlı kayıt tutmak olmadığı yönetimin etkinliğinin ve işletmenin başarısının çok önemli bir anahtarı olduğu iyice anlaşı1mıştır. Önemi bu derece ortada olan muhasebe bilgisinin doğru, tam ve zamanında oluşması ise ancak MBS'nin etkinliği ile mümkündür. Muhasebe karar süreçlerinde sembolik gücünden kaynaklanan bir role de sahiptir. Muhasebe genellikle güvenilir, doğal ve tarafsız olarak algılanır. $\mathrm{Bu}$ durum yönetim tarafından, hem kararların alınma sürecinde hem de kararların değerlendirilme aşamasında muhasebeden güvenilir bir kaynak olarak yararlanılmasını sağlar (Kalmış ve Dalgın, 2010, 115). Muhasebe bilgisinin hata ve hileden uzak olmasının ne kadar önemli olduğu bu bilgilerin işletmeleri, ülkeleri hatta dünya ekonomisini krizlere sokabildiği yaşanan tecrübeler ile görülmüştür. Hata ve hileden arındırılmış muhasebe verileri ise denetim mekanizması ile elde edilebilecektir.

\section{Karaman Organize Sanayi Bölgesinde Bir Uygulama}

Çalışmanın bu bölümünde teorik bölümde ele alınan bilgiler 1şı̆̆ında Karaman Organize Sanayi Bölgesi'nde faaliyet gösteren işletmeler üzerinde yapılan araştırma ile MBS'nin etkinliğinin kurumsallaşma ve denetimle olan ilişkisi anlaşılmaya çalışılmıştır. Araştırmanın amacı, önemi, modeli, kapsamı, yöntemi, hipotezleri, verilerin değerlendirilmesi aşaması ile bilgilere yer verilmiştir

\subsection{Araştırmanın Amacı Ve Önemi}

Günümüz rekabet koşullarında varlığını devam ettirmek ve hedeflerine ulaşmak isteyen işletmelerin fark yaratmaları zorunlu hale gelmiştir. Fark yaratabilmek amaçlarını gerçekleştirmek isteyen işletmeler için en 
büyük güç bilgidir, işletmenin ihtiyaç duyduğu bilgileri sağlayan sistemlerden biri MBS'dir. Bununla birlikte rekabet ortamının her geçen gün daha da çetinleştiği piyasa koşulları işletmeleri bir sistem yaratmaya uzun vadeli düşünmeye kişilerden bağımsız ayakta kalabilecek bir yapı kazanmaya zorlamaktadır. Bunun yolu ise kurumsallaşmadan geçmektedir. Şüphesiz ki kurumsallaşma hedefindeki işletmeler için bilgi olmazsa olmazdir.

Çalışmada karar alıcıların kullanacağı bilgileri üreten MBS ile kurumsallaşma arasındaki bağın öneminin vurgulanması amaçlanmıştır. Yine benzer şekilde, birbirinden ayrı düşünülmesi zor kavramlar haline gelen kurumsallaşma ile denetimin MBS ile etkileşiminin incelenmesi amaçlanmıştır.

Konu ile ilgili birçok benzer çalışma yürütülmüştür. Diğer çalışmalardan farklı olarak, "Kurumsallaşma" ve "Denetim" kavramlarının muhasebe sisteminin etkinliğindeki rolünün Karaman ilinde faaliyet gösteren firmalar tarafından farkedilmesinin sağlanması amaçlanmıştır. Karaman OSB Müdürlügü̆’nden 2018 y1lı mayıs ayında alınan bilgilere göre, Karaman OSB Türkiye'nin bisküvi, gofret, kek, çikolata ürünlerinin yaklaşı \%35'inin üretiminin gerçekleştirildiği, yıllık 242 Milyon \$' lık ihracat yapılan ve ülkedeki diğer OSB'ler arasında 24. Sırada yer alan büyük bir bölgedir. Bu nedenle çalışma bölge firmaları için farkındalık yaratma adına önem arz etmektedir.

\subsection{Araştırmanın Evreni ve Örneklemi}

Araştırmanın evrenini Karaman ilinde faaliyet göstermekte olan ihracat rakamları ile Türkiye ekonomisinde önemli bir yere sahip olan, ekonomik başarılarının yanı sıra Karaman'a sağladıkları sosyal ve kültürel katkıların yanında bölgede de büyük bir istihdam yaratan Karaman Organize Sanayi Bölgesi'nde faaliyet gösteren işletmeler oluşturmaktadır. Karaman Organize Sanayi Bölgesi Müdürlüğü'nden Mayıs 2018'de alınan bilgilere göre Karaman Organize Sanayi Bölgesi'nde aktif faaliyet gösteren 130 firma bulunmaktadır. Araştırmanın uygulaması bu firmaların yönetici ve patron/başkanlarına yapılmıştır. İşletmelerin her birinde her bölüm için ayrı yönetici bulunmadığından ortalama 400 yönetici için evren büyüklükleri belirlenen örnek büyüklüklerine göre bu araştırma için en az 196 kişiye ulaşılması gerekmektedir. Buna göre yapılan 235 anketten geçerli olan 200 anketin değerlendirmesi yapılmıştır.

\subsection{Araştırmanın Yöntemi}

Bu çalışmada veri türlerinden birincil veriler içerisinde yer alan anket yöntemi uygulanmıştır. Anketin yapılmasında yüz yüze görüşme yöntemi uygulanmıştır. Ankete 235 kişi katılmış bunların içinde 35 tanesi cevapsız bırakılan sorular nedeniyle değerlendirmeye alınmamıştır. 200 anket üzerinden değerlendirmeler yapılmıştır.

Anket soruları oluşturulmasında; Varıcı (2007), Karpuzoğlu (2001), Acar ve Ömürbek (2003), Dalgın (2008), Yavuz (2014), Çidem (2013), Akar (2016), Akgün ve Kılıç (2013) çalışmalarından faydalanılmıştır.

Anket formunun demografik bilgiler kısmında kişisel bilgileri içeren 8 soru ve firma bilgilerini içeren 4 soru bulunmaktadır. Birinci kısımda işletmede MBS'den yararlanma düzeylerini ölçmeyi amaçlayan likert tipi ölçekli 10 soru (1:çok az önemli... 5:son derece önemli) yöneltilmiş, ikinci kısımda MBS'nin etkinliğinin kurumsallaşma ve denetimle olan ilişkisini anlamaya yönelik likert tipi ölçekli 37 soru (1 Hiç Katılmıyorum... 5 Tamamen Katılıyorum) yöneltilmiştir (İlgili grubun güvenilirlik analizi sonucunda Cronbach's Alpha; 0,974 olarak hesaplanmıştır). Son kısımda ise tamamlayıcı bilgiler olarak değerlendirilebilecek işletme ile ilgili yargıları içeren 27 soru (Evet-Hayır) yöneltilmiştir.

Araştırmanın örneklemini üretim işletmelerinde MBS'nin daha çok kullanılması ve belge-bilgi akışının daha çok olması nedeniyle organize sanayi bölgesinde olan üretim işletmeleri oluşturmaktadır.

\subsection{Araştırmanın Hipotezleri}

$\mathrm{Bu}$ araştırmanın temel amacı teorik bölümde ayrı ayrı ele alınan ve ilişkileri ile ilgili temel bilgilerin incelendiği MBS, kurumsallaşma ve denetim kavramlarının ilişkilerinin ortaya konmasıdır.

Tüm yöneticilerin temel amacı işletmelerini etkin ve etkili bir biçimde yöneterek hedeflerine ulaşmaktır. Etkin bir yönetimde kurumsallaşma denetim ve muhasebe bilgi sistemlerinin önemini ve ilişkilerini ortaya koyan 3 ana hipotez şöyledir:

H1: İşletmenin genel yönetim kararları ile MBS'nin etkin kullanımı arasında anlamlı bir ilişki vardır.

H2: İşletmelerde kurumsallaşma düzeyi ile MBS'nin etkin kullanımı arasında anlamlı bir ilişki vardır.

H3: İşletmelerde kurumsallaşma düzeyi ile işletmelerdeki etkin denetim arasında anlamlı biri ilişki vardır. 


\subsection{Araştırmanın Modeli}

Araştırmanın modeli oluşturulurken MBS' nin etkinliği, kurumsallaşma ve denetimin etkinliği arasındaki ilişki, $\mathrm{p}<0.05$ güven aralığında yapılan ki-kare ile belirlenmeye çalışılmış, ilişkinin derecesinin belirlemek içinse korelasyon katsayısı değerlendirilmiştir. Korelasyon Katsayısının Değeri (r) $0.00-0.19$ arasında ise ilişki yok ya da önemsenmeyecek düzeyde düşük, $0.20-0.39$ arasında ise zayıf (düşük) ilişki, $0.40-0.69$ arasında ise orta düzeyde ilişki, $0.70-0.89$ arasında ise kuvvetli (yüksek) ilişki, $0.90-1.00$ arasında ise çok kuvvetli ilişki şeklinde değerlendirilmiştir.

Ayrıca çalışmada açıklayıcı faktör analizi kullanılmış MBS 'nin etkinliği ile ilgili faktörler, MBS'nin kayıt, raporlama, bilgilendirme ve değerlendirme süreçleri etkinliği, insan kaynakları ile ilgili kararlarda etkinliği, finansman ile ilgili kararlarda etkinliği, genel yönetim kararlarında etkinliği, üretim ile ilgili kararlarda etkinliği ve pazarlama ile ilgili kararlarda etkinliği olmak üzere altı grup olarak belirlenmiştir.

Kurumsallaşma ile ilgili ise gruplar 3 faktöre ayrılmış ve sırasıyla; kurumsallaşma organizasyon ve insan kaynakları boyutu, kurumsallaşma güvenilirlik boyutu ve kurumsallaşma şeffaflık boyutu olarak belirlenmiştir. Ayrıca kurumsallaşma ve sosyal sorumluluk arasındaki ilişki de ki-kare ve korelasyon analizi ile belirlenmeye çalışılmıştır.

\section{Şekil.1 Araştırma Modeli}

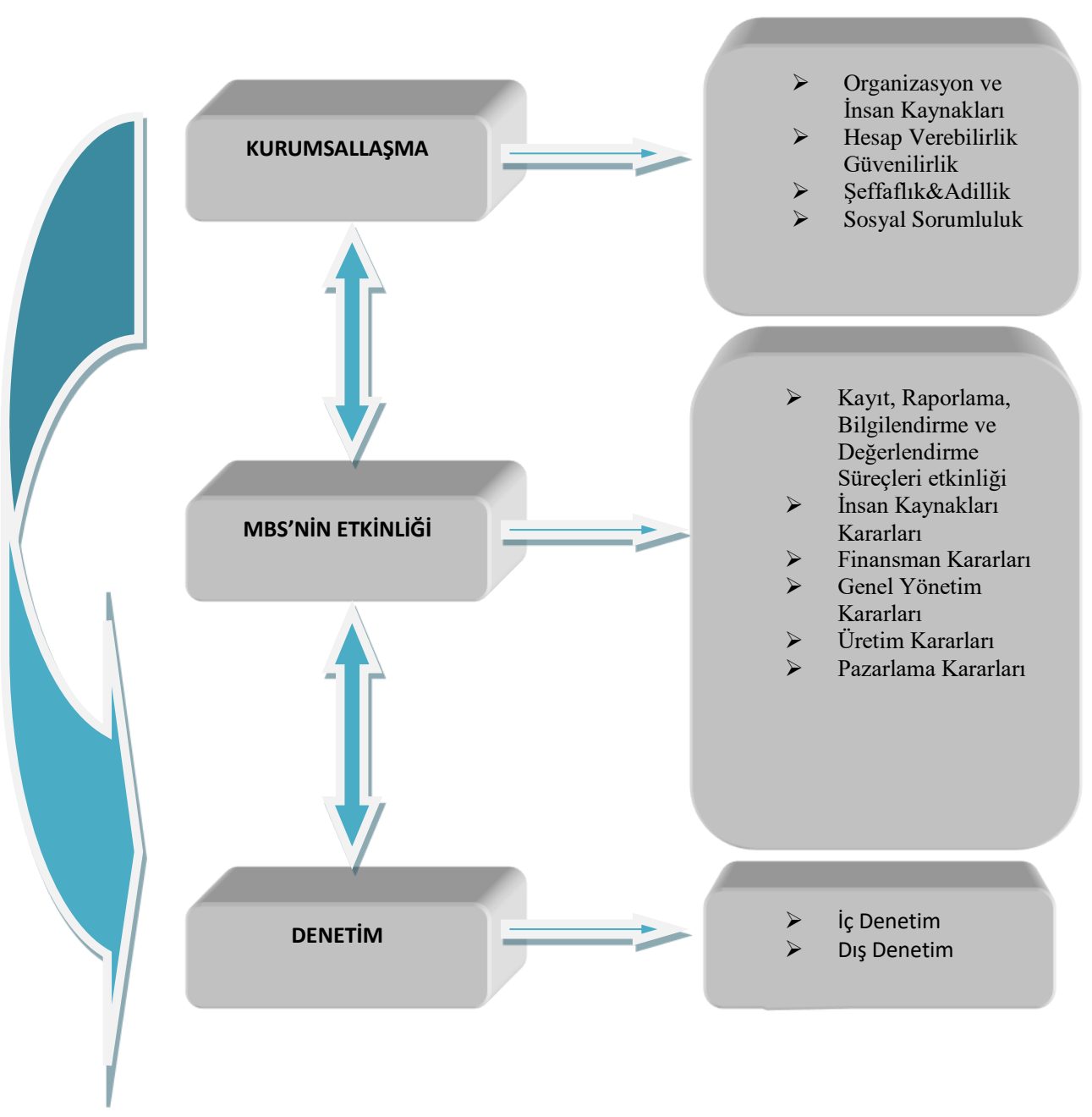




\subsection{Araştırma Verilerinin Değerlendirilmesi}

Tablo 1'de katılımcılar ilişkin demografi veriler yer almaktadır.

Tablo 1. Katılımelara Ait Demografik Bilgiler

\begin{tabular}{|c|c|c|c|c|c|}
\hline Cinsiyet & Frekans & $\%$ & Departman & Frekans & $\%$ \\
\hline Erkek & 136 & 68 & Muh/Finansman & 30 & 15 \\
\hline Kadın & 64 & 32 & İnsan Kaynakları & 38 & 19 \\
\hline Yaş & Frekans & $\%$ & Satın Alma & 22 & 11 \\
\hline $26-35$ & \begin{tabular}{|l|}
40 \\
\end{tabular} & 20 & İhracat & 26 & 13 \\
\hline $36-45$ & 122 & 61 & Satış Pazarlama & 30 & 15 \\
\hline $46-54$ & 28 & 14 & Üretim & 34 & 17 \\
\hline $55+$ & 10 & 5 & Ĕgitim Durumu & Frekans & $\%$ \\
\hline Unvan & Frekans & $\%$ & Lise & 12 & 6 \\
\hline Başkan/Patron & 8 & 4 & Yüksek Okul & 50 & 25 \\
\hline Genel Müdür & 12 & 6 & Lisans & 124 & 62 \\
\hline Bölüm Müdürü & 180 & 90 & Yüksek Lisans & 14 & 7 \\
\hline Sektör Tecrübesi & Frekans & $\%$ & İsyeri Tecrübesi & Frekans & $\%$ \\
\hline 1 Yildan $\mathrm{Az}$ & & & 1 Yildan $\mathrm{Az}$ & 6 & 3 \\
\hline $1-2 Y_{11}$ & 8 & 4 & $1-2$ Yil & 32 & 16 \\
\hline $3-5 Y_{11}$ & 42 & 21 & $3-5 Y_{11}$ & 76 & 38 \\
\hline 6-10 Y11 & 66 & 33 & 6-10 Y11 & 57 & 28,5 \\
\hline $11+Y_{11}$ & 84 & 42 & $11+Y_{11}$ & 29 & 14,5 \\
\hline
\end{tabular}

Katılımcıların cinsiyete göre dağılımları incelendiğinde \%68 ini erkek, \%32 sini kadın katılımcıların oluşturduğu görülmektedir. Bu sonuçlar değerlendirildiğinde Karaman OSB'de faaliyet gösteren firmalarda erkek yöneticilerin ağırlıkta olduğu düşünülebilir.

Çalışmaya katılan cevaplayıcıların \%61'i 36-45 yaş arasında, \%20'si 26-35 yaş, \%14'ü 46-54 yaş ve \%5' lik kısmı ise 55 yaş üzerindedir. Bu sonuçlara bakılarak çalışmaya katılanların \%80 den fazlasının 26-45 yaş aralığında olduğu değerlendirilebilir.

Cevaplayıcıların eğitim durumlarına bakıldığında \%62 lik büyük bir kısmın lisans mezunu olduğu görülürken lisans ve yüksek lisans mezunlarının toplamı yaklaşık \%70 tir.

\subsection{Araştırma Hipotezlerine İlişkin Değerlendirmeler}

Tablo 2.'de "H1 İşletmenin genel yönetim kararları ile MBS'nin etkin kullanımı arasında anlamlı bir ilişki vardır." hipotezine ilişkin test sonuçları verilmiştir. 
Tablo 2. İşletmelerde Muhasebe Bilgi Sisteminin Etkinliği Ve Genel Yönetim Kararlarında Muhasebe Bilgi Sisteminin Önem Düzeyi

\begin{tabular}{|c|c|c|c|c|c|}
\hline \multirow{2}{*}{\multicolumn{2}{|c|}{\begin{tabular}{|c} 
SORULAR/ÖNEM DÜZEYI \\
MBS'nin Etkinliğini Ölçmeye Yönelik Sorular
\end{tabular}}} & \multicolumn{4}{|c|}{$\begin{array}{c}\text { GENEL YÖNETIM KARARLARINDA MBS'NIN } \\
\text { ETKINNLIK DÜZEYI }\end{array}$} \\
\hline & & $\begin{array}{c}\text { Ki-Kare } \\
\left(x^{2}\right)\end{array}$ & df & $\begin{array}{l}\text { Korelasyon } \\
\text { Katsayısı (r) }\end{array}$ & $\mathbf{P}($ sig. $)$ \\
\hline \multicolumn{2}{|c|}{ Pazarlama ve Satış Stratejileri Geliştirilmesinde } & 13,43 & 4 & $\mathbf{0 , 5 8 0}$ & $\mathbf{0 , 0 0 2} * *$ \\
\hline \multicolumn{2}{|l|}{ Finansman İhtiyacının Belirlenmesinde } & 32,45 & 12 & 0,692 & $\mathbf{0 , 0 0 0} * *$ \\
\hline \multicolumn{2}{|c|}{ İstihdam Edilecek Personelin Sayısının Belirlenmesinde } & 36,73 & 12 & 0,386 & $0,005 * *$ \\
\hline \multicolumn{2}{|c|}{ Personele ödenecek ücret politikasının belirlenmesinde } & 21,56 & 16 & 0,399 & $0,005 * *$ \\
\hline \multicolumn{2}{|l|}{ İşletmenin yapacağı yatırım kararlarında } & 43,41 & 16 & 0,658 & $0,007 * *$ \\
\hline \multicolumn{2}{|c|}{ Tedarikçilerin tespitinde ve satın alma kararlarında } & 17,19 & 16 & 0,610 & $0,000 * *$ \\
\hline \multicolumn{2}{|c|}{ AR-GE için ayrılacak bütçenin belirlenmesinde } & 21,27 & 8 & 0,546 & $\mathbf{0 , 0 0 0 * *}$ \\
\hline \multicolumn{2}{|c|}{ Makine, teçhizat ve demirbaş yenileme kararlarında } & 87,41 & 12 & 0,643 & $0,021 * *$ \\
\hline \multicolumn{2}{|l|}{ İşletmenin genel yönetim kararlarında } & 83,39 & 6 & 0,675 & $\mathbf{0 , 0 0 0} * *$ \\
\hline \multicolumn{2}{|l|}{ Maliyetlerin Azaltılmasında } & 43,57 & 12 & 0.715 & $0,003 * *$ \\
\hline \multicolumn{6}{|c|}{ İşletme Demografik Özellikleri ile İşletmede Muhasebe Bilgi Sisteminin Etkinlik Düzeyi } \\
\hline İşletmelerin Demografik Özellikleri & $\begin{array}{l}\text { Ki-Kare } \\
\qquad\left(x^{2}\right)\end{array}$ & df & \multicolumn{2}{|c|}{\begin{tabular}{|c|} 
Korelasyon \\
Katsayısı (r)
\end{tabular}} & P(sig.) \\
\hline İşletmenin büyüklüğü (Çalışan sayısı) & 32,548 & 6 & & 0,514 & $0,000 * *$ \\
\hline İşletmenin tüzel kişiliği & 27,524 & 16 & & 0,487 & $0,003 * *$ \\
\hline İşletmenin faaliyet süreleri & 37,113 & 12 & & 0,411 & $0,001 * *$ \\
\hline İşletmenin faaliyet sektörü & 69,347 & 21 & & 0,226 & $0,000 * *$ \\
\hline \multicolumn{6}{|c|}{ Önem Düzeyi: **p<0,05 } \\
\hline
\end{tabular}

Tabloda yönetim kararları ile MBS'nin etkin kullanımı arasındaki ilişki incelenmiştir. Ki kare değerine ilişkin anlamlılık düzeyi değerlendirildiğinde tüm kararlar ile MBS'nin etkin kullanımı arasında ( $\mathrm{p}=0,000)$ anlamlı bir ilişki olduğu görülmektedir. Korelasyon katsayıları ( $\mathrm{r}$ değeri) incelendiğinde özellikle finansman ve yatırım kararları ile genel yönetim kararlarında MBS'nin etkin kullanımı arasında güçlü bir ilişki olduğu, Ar-ge ve pazarlama ile ilgili kararlarla MBS'nin etkin kullanımı arasında orta düzeyde bir ilişki olduğu insan kaynaklarını ilgilendiren kararlar ile MBS'nin etkin kullanımı arasında ise zayıf bir ilişki olduğu anlaşılmaktadır. Genel olarak bakıldığında işletmenin genel yönetim kararları ile MBS'nin etkin kullanımı arasında anlamlı bir ilişki bulunmaktadır. Bundan dolayı H1 kabul edilir.

H1A: İşletmede pazarlama ve satış stratejileri geliştirmede MBS'den yararlanılır. İşletmede pazarlama ve satış stratejileri geliştirmesinde MBS etkinlik düzeyi arasında (r: 0.580) orta düzeyde bir ilişki söz konusudur. Bundan dolayı H1 A kabul edilir.

H1B: İşletmenin finansman kararlarının belirlenmesinde MBS'den yararlanılır. İşletmenin finansman kararlarının belirlenmesinde MBS etkinlik düzeyi arasında (r: 0.692) orta düzeyde bir ilişki söz konusudur. Bundan dolayı H1B kabul edilir.

H1C: İşletmede istihdam edilecek personelin sayısını belirlemede MBS'den yararlanılır. İşletmede istihdam edilecek personelin sayısını belirlemede MBS etkinlik düzeyi arasında (r: 0.386) zayıf düzeyde bir ilişki söz konusudur. Bundan dolayı H1C kabul edilir. 
H1D: İşletmede personele ödenecek ücret politikasının belirlenmesinde MBS'den yararlanılır. İşletmede personele ödenecek ücret politikasının belirlenmesinde MBS etkinlik düzeyi arasında (r: 0.399) zayıf düzeyde bir ilişki söz konusudur. Bundan dolayı H1D kabul edilir.

H1E: İşletmenin yapacağı yatırım kararlarında MBS'den yararlanılır. İşletmenin yapacağ 1 yatırım kararlarında MBS etkinlik düzeyi arasında (r: 0.658) orta düzeyde bir ilişki söz konusudur. Bundan dolayı H1E kabul edilir.

H1F: İşletmede tedarikçilerin tespitinde ve satın alma kararlarında MBS'den yararlanılır. İşletmede tedarikçilerin tespitinde ve satın alma kararlarında MBS etkinlik düzeyi arasında (r: 0.610) orta düzeyde bir ilişki söz konusudur. Bundan dolayı H1F kabul edilir.

H1G:İşletmede araştırma geliştirme (AR-GE) faaliyetleri için ayrılacak bütçenin belirlenmesinde MBS'den yararlanılır. İşletmede araştırma geliştirme (AR-GE) faaliyetleri için ayrılacak bütçenin belirlenmesinde MBS etkinlik düzeyi arasında (r: 0.546) orta düzeyde bir ilişki söz konusudur. Bundan dolayı H1G kabul edilir.

H1H: İşletmede Makine, teçhizat ve demirbaş yenileme kararlarında MBS'den yararlanılır. İşletmede Makine, teçhizat ve demirbaş yenileme kararlarında MBS etkinlik düzeyi arasında (r: 0.643) orta düzeyde bir ilişki söz konusudur. Bundan dolayı $\mathrm{H} 1 \mathrm{H}$ kabul edilir.

H1I: İşletmenin genel yönetim kararlarında MBS'den yararlanılır. İşletmenin genel yönetim kararlarında MBS etkinlik düzeyi arasında (r: 0.675) orta düzeyde bir ilişki söz konusudur. Bundan dolayı H1I kabul edilir.

H1J: İşletmede maliyetlerin azaltılmasında MBS'den yararlanılır. İşletmede maliyetlerin azaltılmasında MBS etkinlik düzeyi arasında (r: 0.715) kuvvetli (yüksek) düzeyde bir ilişki söz konusudur. Bundan dolayı H1J kabul edilir.

İşletmenin çalışan sayısı ve tüzel kişilik ile MBS'nin etkin kullanımı arasında orta düzeyde anlamlı bir ilişki olduğu görünmektedir. Çalışan sayısı arttıkça işletmenin büyüdüğü ve ihtiyaç duyulan raporların ve bilgi belge akışının arttığı düşünülürse MBS'nin etkin kullanımının öneminin de artacağı düşünülebilir.

H1K: İşletmenin büyüklüğü (işletmede çalışan sayısı) ile MBS'nin etkin kullanımı arasında anlamlı bir ilişki vardır. İşletmenin büyüklüğü ile MBS'nin etkin kullanımı arasında r:0,514 olduğundan orta düzeyde anlamlı bir ilişki vardır. Bundan dolayı H1K kabul edilir.

H1L: İşletmenin tüzel kişiliği ile MBS'nin etkin kullanımı arasında anlamlı bir ilişki vardır. İşletmenin tüzel kişiliği ile MBS'nin etkin kullanımı arasında r:0,487 olduğundan orta düzeyde anlamlı bir ilişki vardır. Bundan dolayı H1L kabul edilir.

H1M: İşletmenin faaliyet süresi ile MBS'nin etkin kullanımı arasında anlamlı bir ilişki vardır. İşletmenin faaliyet süresi ile MBS'nin etkin kullanımı arasında r:0,411 olduğundan orta düzeyde anlamlı bir ilişki vardır. Bundan dolayı H1M kabul edilir.

H1N: İşletmenin faaliyet sektörü ile MBS'nin etkin kullanımı arasında anlamlı bir ilişki vardır. İşletmenin faaliyet sektörü ile MBS'nin etkin kullanımı arasında r:0,226 olduğundan zayıf düzeyde anlamlı bir ilişki vardır. Bundan dolayı H1N kabul edilir

Tablo 3'te ise Muhasebe Bilgi Sisteminin etkinliğini ölçmeye yönelik olarak yapılan faktörlerin analizinin sonuçları paylaşılmıştır.

Tablo 3. İşletmelerde Muhasebe Bilgi Sisteminin Etkinliğine Yönelik Faktör Analizi

\begin{tabular}{|c|c|c|c|}
\hline Faktör & Faktör Alt Maddeleri & Faktör Yükü & Faktör Varyansı \\
\hline 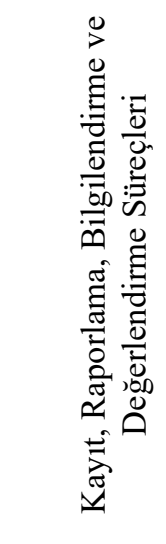 & $\begin{array}{l}\text {-MBS'den raporlar ihtiyaç duyulduğu anda alınabilmektedir } \\
\text { - MBS işletmenin finansal performansı hakkında doğru ve } \\
\text { güvenilir bilgi verir } \\
\text {-Doğru,anlamlı, güncel finansal bilgiler ancak MBS ile } \\
\text { sağlanabilir } \\
\text {-Raporlar yöneticilerin istediği zaman ulaşabi leceği biçimde } \\
\text { düzenli olarak hazırlanır } \\
\text {-İsletmede ihtiyaç duyulan tüm rapor ve bilgiler MBS } \\
\text { aracılığı ile sağlanır } \\
\text {-İşletmede MBS'den elde edilen bilgilere diğer departmanlar } \\
\text { da ihtiyaç duyar }\end{array}$ & $\begin{array}{l}590 \\
543\end{array}$ & 18.2 \\
\hline
\end{tabular}




\begin{tabular}{|c|c|c|c|}
\hline 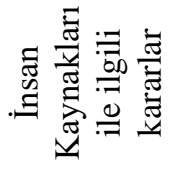 & $\begin{array}{l}\text { - Personele ödenecek ücret politikasının belirlenmesinde } \\
\text {-İstihdam edilecek personelin sayısının belirlenmesinde }\end{array}$ &, 756 & 13.01 \\
\hline 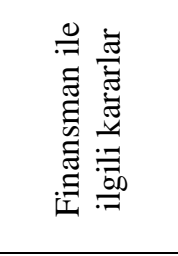 & $\begin{array}{l}\text {-Finansman ihtiyacının belirlenmesi ve ilgili kararların } \\
\text { verilmesinde } \\
\text {-İşletmenin yapacağı yatırım kararlarında } \\
\text {-Finansman faaliyetlerinde MBS'deki bilgilerden } \\
\text { faydalanma }\end{array}$ & $\begin{array}{l}, 802 \\
, 769 \\
, 759\end{array}$ & 10.21 \\
\hline 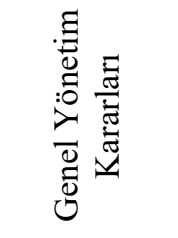 & $\begin{array}{l}\text {-Makine, Teçhizat ve Demirbaş yenileme kararlarında } \\
\text {-İşletmenin genel yönetim kararlarında } \\
\text {-AR-GE için ayrılacak bütçenin belirlenmesinde }\end{array}$ & $\begin{array}{l}837 \\
829 \\
, 821\end{array}$ & 8.33 \\
\hline 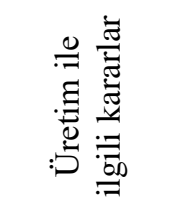 & $\begin{array}{l}\text {-Maliyetlerin azaltılmasında } \\
\text {-Üretimin planlanmasında } \\
\text {-Hammadde ve malzeme tedarikinde }\end{array}$ & $\begin{array}{l}, 820 \\
, 793 \\
, 764\end{array}$ & 7.82 \\
\hline 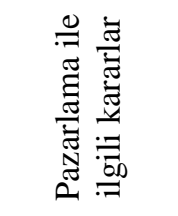 & $\begin{array}{l}\text {-Tedarikçilerin tespitinde ve satın alma kararlarında } \\
\text {-Pazarlama ve Satış Stratejileri Geliştirmesinde } \\
\text {-Pazar değerleme, fiyat sipariş-satış-maliyet konularında }\end{array}$ & $\begin{array}{l}, 840 \\
, 826 \\
, 644\end{array}$ & 7.21 \\
\hline Barlett' & $\begin{array}{c}\text { KMO: } 0,860 \\
\text { Test of Sphericity - Sig: } \mathbf{0 , 0 0 0} \\
\text { Toplam Cronbach Alpha }=\mathbf{0 , 8 7}\end{array}$ & \multicolumn{2}{|c|}{ Toplam Varyans: $\% 64,78$} \\
\hline
\end{tabular}

Birbiriyle orta ya da yüksek düzeyde ilişkili anket soruları 5'li likert ölçeği kullanılmak suretiyle çalışmaya dahil edilmiştir. Çok sayıda olabilen değişkenlerin birkaç başlık altında toplanabilmesini sağlamak amacıyla faktör analizi yapılmıştır.

Çalışmada açıklayıcı faktör analizi kullanılmış olup faktörler altı gruba ayrılmaktadır. Grupların soru dağılımları Tablo 3.’te gösterilmektedir. Gruplar sırasıyla; MBS'nin Kayıt, Raporlama, Bilgilendirme ve Değerlendirme Süreçleri etkinliği, İnsan Kaynakları ile ilgili kararlarlarda etkinliği, Finansman ile ilgili kararlarda etkinliği, Genel Yönetim Kararlarında etkinliği, Üretim ile ilgili kararlarda etkinliği ve Pazarlama ile ilgili kararlarda etkinliği olarak belirlenmiştir. Faktör analizi yapmak için, veri setinin faktör analizine uygunluğunu, analizin geçerliliğini ve örneklemin büyüklüğünün yeterliliğini gösteren KaiserMeyer-Olkin (KMO) testinde hesaplanan değer 0,860'dır. Faktör analizi yapabilmek için KMO değerinin 0,60 dan büyük olması beklenir. 0,860 değeri faktör analizi yapmak için örneklem büyüklüğünün yeterli olduğunu göstermektedir. Değişkenler arasında faktör analizi yapılabilecek güçte anlamlı bir ilişki olup olmadığını gösteren Barletts testi değeri 0,05'den küçük çıktığı için değişkenler arasında anlamlı bir ilişki olduğu Tablo 3.'teki Sig: 0,000 değerinden anlaşılmaktadır. İfadelerin güvenirliliğinin ve kendi içinde tutarlılığının ölçülmesinde Cronbach Alpha değeri kullanılmakta olup, bu değerin en az 0,70 olması istatistiksel olarak kabul gören bir durumdur. Ancak bazı kaynaklarda 0,50’ye kadar bu değerin makul değerlendirilebileceği de belirtilmektedir. Tablo 3. incelendiğinde toplam Cronbach Alpha Değeri 0.87 olarak bulunmuş olup bütün ifadelerin güvenilir olduğu söylenebilir. 6 faktörlü bir yapıda hiçbir değişkenin Cronbach-alfa katsayılarının 0.70'in altında olmadığ 1 göz önüne alındığında bu faktörlerin güvenilirliği ile ilgili bir sorun yaşanmadığ 1 söylenebilir. Bu 6 faktör tüm yapıdaki değişimin (varyansın) yaklaşık yüzde 65'ini açılamaktadır. KMO değeri oldukça yüksektir ve veri setinin faktör analizine tabi tutulmak içi yeterli sayıda olduğunun göstergesidir.

MBS'nin etkin kullanılmasının kayıt, raporlama, bilgilendirme ve değerlendirme süreçlerinde; MBS'den raporların ihtiyaç duyulduğu anda alınabilmesine, işletmenin finansal performansı hakkında doğru ve güvenilir bilgi vermesine, doğru, anlamlı, güncel finansal bilgilerin sağlanmasına, raporların yöneticilerin istediği zaman 
ulaşabileceği biçimde düzenli olarak hazırlanmasına, işletmede ihtiyaç duyulan tüm rapor ve bilgilerin MBS aracılığ1 ile sağlanmasına ve işletmede MBS'den elde edilen bilgilere diğer departmanların da ihtiyaç duymasına yönelik ifadelerden oluşmaktadır. MBS'nin etkinliğinin insan kaynakları ile ilgili kararların; personele ödenecek ücret politikasının belirlenmesi ve istihdam edilecek personelin sayısının belirlenmesinde etkili olacağını ifade etmektedir. MBS'nin finansman ile ilgili kararlarda etkinliği ise finansman ihtiyacının belirlenmesi, ilgili kararların verilmesi, işletmenin yapacağı yatırım kararlarında ve finansman faaliyetlerinde MBS'deki bilgilerden faydalanma ifadelerinden oluşan bir faktördür. Genel Yönetim Kararları açısından MBS'nin etkinliği faktörü; makine, teçhizat ve demirbaş yenileme kararlarında, işletmenin genel yönetim kararlarında, AR-GE için ayrılacak bütçenin belirlenmesinde etkilidir ifadelerinden oluşmaktadır. MBS'nin üretim ile ilgili kararlarda etkinliği; maliyetlerin azaltılmasında, üretimin planlanmasında, hammadde ve malzeme tedarikinde öne çıkacağını işaret etmektedir. MBS'nin pazarlama ile ilgili kararlarda etkinliği ise tedarikçilerin tespitinde, satın alma kararlarında, pazarlama ve satış stratejileri geliştirmesinde, pazar değerleme, fiyat, sipariş-satış-maliyet konularında olumlu etkileyeceğini ifade eden maddelerden oluşan bir faktördür.

Tablo 4'te "H2: İşletmelerde kurumsallaşma düzeyi ile MBS'nin etkin kullanımı arasında anlamlı bir ilişki vardır." hipotezine ilişkin test sonuçları verilmiştir.

Tablo 4. İşletmede Kurumsallaşma ile İşletmede Muhasebe Bilgi Sisteminin Etkinlik Düzeyi

\begin{tabular}{|c|c|c|c|c|c|}
\hline \multicolumn{6}{|c|}{ İşletmede Kurumsallaşma ile İşletmede MBS'nin Etkinlik Düzeyi } \\
\hline Kurumsallaşma Düzeyi & MBS ETKIN \% & \multicolumn{2}{|c|}{$\begin{array}{c}\text { MBS ETKİN } \\
\text { DEĞIL \% }\end{array}$} & $\begin{array}{c}\text { Toplam } \\
\%\end{array}$ & $\mathbf{P}($ sig. $)$ \\
\hline Kurumsal İşletme & 82 & \multicolumn{2}{|l|}{18} & 100 & $0,000^{* *}$ \\
\hline Kurumsallaşmamıș İşletme & 24 & \multicolumn{2}{|l|}{76} & 100 & $0,000^{* *}$ \\
\hline \multicolumn{4}{|c|}{ Korelasyon Katsayısı r: 0,712 } & \multicolumn{2}{|c|}{$\mathrm{P}(\mathrm{sig}) .0,000$} \\
\hline \multicolumn{6}{|c|}{ Demografik Özellikleri ile İşletmenin Kurumsallaşma Düzeyi } \\
\hline İşletmelerin Demografik Özellikleri & $\begin{array}{c}\text { Ki-Kare } \\
\left(x^{2}\right) \\
\end{array}$ & df & & $\begin{array}{l}\text { Korelasyon } \\
\text { Katsayısı (r) }\end{array}$ & $\mathbf{P}($ sig. $)$ \\
\hline İşletmenin büyüklüğü (Çalışan sayısı) & 23,68 & 12 & & 0,611 & $0,000^{* *}$ \\
\hline İşletmenin faaliyet süreleri & 27,45 & 16 & & 0,581 & $0,000^{* *}$ \\
\hline İşletmenin tüzel kişiliği & 45,21 & 21 & & 0,522 & $0,001 * *$ \\
\hline İşletmenin faaliyet sektörü & 41,13 & 21 & & 0,187 & $0,000^{* *}$ \\
\hline Yöneticilerin sektör tecrübeleri & 22,14 & 16 & & 0,238 & $0,001 * *$ \\
\hline Yöneticilerin eğitim durumları & 31,37 & 21 & & 0,217 & $0,001 * *$ \\
\hline \multicolumn{6}{|c|}{ İşletme - Çalışan - Yönetim Arası İlişkiler Açısından İşletmenin Kurumsallaşma Düzeyi } \\
\hline \multicolumn{2}{|c|}{ Kurumsal işletmelerde, çalışan-yönetim-işletme arası ilişsiler } & Ki-Kare $\left(x^{2}\right)$ & df & $\begin{array}{c}\text { Korelasyon } \\
\text { Katsayısı (r) }\end{array}$ & $\mathbf{P}($ sig. $)$ \\
\hline \multicolumn{2}{|c|}{$\begin{array}{l}\text { İşletmede iş bölümü ve uzmanlaşmaya yönelik bir yapılanma söz } \\
\text { konusudur. }\end{array}$} & 31,54 & 6 & 0,573 & $0,000 * *$ \\
\hline \multicolumn{2}{|c|}{ İşletmede departmanlar arası bağımsızlık mevcuttur. } & 37,25 & 6 & 0,554 & $0,000 * *$ \\
\hline \multicolumn{2}{|c|}{ İşletmede çalışanlar yeteneklerine göre terfi ettirilmektedir. } & 33,47 & 12 & 0.287 & $0,001 * *$ \\
\hline \multicolumn{2}{|c|}{$\begin{array}{l}\text { Aile üyesi olmayan yöneticilerin yetki ve sorumlulukları } \\
\text { kısitlıdır. }\end{array}$} & 19,21 & 16 & 0,187 & 0,12 \\
\hline \multicolumn{2}{|c|}{ Çalışanlar yakın akrabalardan tercih edilmemektedir } & 21,13 & 16 & 0,125 & 0,15 \\
\hline \multicolumn{2}{|c|}{$\begin{array}{l}\text { Çalışanların işletmeye karşı hissettikleri aidiyetlik duygusu } \\
\text { fazladır }\end{array}$} & 47,35 & 4 & 0,258 & $0,001 * *$ \\
\hline
\end{tabular}




\begin{tabular}{|l|c|c|c|c|}
\hline İşletmenin karar alma süreçlerinde çalışanların katılımı yüksektir. & 49,28 & 6 & 0,174 & 0,14 \\
\hline Çalışanların yönetime olan güveni yüksektir. & 22,44 & 12 & 0,298 & $0,001 * *$ \\
\hline \multicolumn{4}{|c|}{ Sosyal Sorumluluk Açısından İşletmenin Kurumsallaşma Düzeyi } \\
\hline Kurumsal işletmelerde sosyal sorumluluk & $\begin{array}{c}\text { Ki-Kare } \\
\left(\boldsymbol{x}^{2}\right)\end{array}$ & $\begin{array}{c}\text { Korelasyon } \\
\text { Kats } \\
\text { Kayısı (r) }\end{array}$ & P(sig.) \\
\hline İşletme sosyal sorumluluk projelerine katkı sağlar & 33,74 & 12 & 0,584 & $0,000^{* *}$ \\
\hline $\begin{array}{l}\text { İşletme sosyal sorumluluk projelerinde ilimizin/ülkemizin tanıtımına } \\
\text { katkı sağlar. }\end{array}$ & 27,87 & 6 & 0,325 & $0,000^{* *}$ \\
\hline İşletme uzun vadede toplumun refah düzeyini dikkate alır. & 26,68 & 12 & 0,176 & 0.12 \\
\hline İşletme değişime öncülük eder. & 29,18 & 14 & 0,185 & 0,15 \\
\hline Paydaşlarının gözünde işletme güvenilir bir imaja sahiptir. & 16,06 & 12 & 0.274 & $0,001 * *$ \\
\hline
\end{tabular}

Önem Düzeyi: **p<0,05

H2: İşletmelerde kurumsallaşma düzeyi ile MBS'nin etkin kullanımı arasında anlamlı bir ilişki vardır. MBS'nin etkinliği ve kurumsallaşma ilişkisi incelendiğinde (r: 0.712) kuvvetli derecede anlamlı bir ilişki olduğu yani $\mathrm{H} 2$ nin kabul olduğu görülmektedir.

H2A: İşletmelerin kurumsallaşma düzeyi ile işletmelerin büyüklüğü (işletmelerin çalışan sayısı) arasında anlamlı bir ilişki vardır. İşletmenin büyüklüğü ile kurumsallaşma arasında kuvvetli bir ilişki olduğu (r: 0.611) değerlendirilebilmektedir. Dolayısıyla H2A hipotezi kabul edilir.

H2B: İşletmelerin kurumsallaşma düzeyi ile işletmelerin faaliyet süreleri arasında anlamlı bir ilişki vardır.

H2C: İşletmelerin kurumsallaşma düzeyi ile işletmelerin tüzel kişilikleri arasında anlamlı bir ilişki vardır. İşletmenin faaliyet süresi ile kurumsallaşma arasında orta düzeyde bir ilişki olduğu (r: 0.581) yine işletmenin tüzel kişiliği ile kurumsallaşma arasında orta düzeyde bir ilişki olduğu (r: 0.522) değerlendirilebilir. Bundan dolay1 $\mathrm{H} 2 \mathrm{~B}$ ve $\mathrm{H} 2 \mathrm{C}$ hipotezleri de kabul edilir.

H2D: İşletmelerin kurumsallaşma düzeyi ile işletmelerin faaliyet sektörleri arasında anlamlı bir ilişki vardır. İşletmenin faaliyet sektörü ile kurumsallaşması arasında (r: 0.187) bir ilişki yoktur ya da önemsenmeyecek düzeyde ilişki olduğu görülmektedir. Bu nedenle H2D hipotezi reddedilir.

H2E: İşletmelerin kurumsallaşma düzeyi ile işletmelerdeki yöneticilerin sektör tecrübeleri arasında anlamlı bir ilişki vardır.

H2F: İşletmelerin kurumsallaşma düzeyi ile işletmelerdeki yöneticilerin eğitim düzeyleri arasında anlamlı bir ilişki vardır. Yöneticilerin sektör tecrübeleri ile kurumsallaşma arasında (r: 0.238 ) ve yöneticilerin eğitim durumları ile kurumsallaşma arasında (r: 0,217) zayıf bir ilişki olduğu görülmektedir. Bundan dolayı H2E ve H2F hipotezleri de kabul edilir

H2G: İşletmelerdeki kurumsallaşma düzeyi ile işletmede iş bölümü ve uzmanlaşmaya yönelik bir yapılanma olması arasında anlamlı bir ilişki vardır. İşletmelerdeki kurumsallaşma düzeyi ile işletmede iş bölümü ve uzmanlaşmaya yönelik bir yapılanma olması arasında (r: 0.573) orta düzeyde bir ilişki olduğu görülmektedir. Bundan dolayı $\mathrm{H} 2 \mathrm{G}$ hipotezi kabul edilir.

H2H: İşletmelerdeki kurumsallaşma düzeyi ile işletmede departmanlar arası bağımsızlık olması arasında anlamlı bir ilişki vardır. İşletmelerdeki kurumsallaşma düzeyi ile işletmede departmanlar arası bağımsızlık olması arasında (r: 0.554) orta düzeyde bir ilişki olduğu görülmektedir. Bundan dolayı H2H hipotezi kabul edilir.

H2I: İşletmelerdeki kurumsallaşma düzeyi ile işletmedeki çalışanların yeteneklerine göre terfi ettirilmesi arasında anlamlı bir ilişki vardır. İşletmelerdeki kurumsallaşma düzeyi ile işletmedeki çalışanların yeteneklerine göre terfi ettirilmesi arasında (r: 0.287) zayıf düzeyde bir ilişki olduğu görülmektedir. Bundan dolayı H2I hipotezi kabul edilir.

H2J: İşletmelerdeki kurumsallaşma düzeyi ile işletmedeki aile üyesi olmayan yöneticilerin yetki ve sorumluluklarının kısıtlı olması arasında anlamlı bir ilişki vardır. İşletmelerdeki kurumsallaşma düzeyi ile işletmedeki aile üyesi olmayan yöneticilerin yetki ve sorumluluklarının kısıtlı olması arasında (r: 0.187 ve p: 0.12) bir ilişki yoktur ya da önemsenmeyecek düzeyde ilişki olduğu görülmektedir. Bundan dolay1 H2J hipotezi reddedilmiştir 
H2K: İşletmelerdeki kurumsallaşma düzeyi ile işletmedeki çalışanların yakın akrabalardan tercih edilmemesi arasında anlamlı bir ilişki vardır. İşletmelerdeki kurumsallaşma düzeyi ile işletmedeki çalışanların yakın akrabalardan tercih edilmemesi arasında (r: 0.125 ve p: 0.15 ) bir ilişki yoktur ya da önemsenmeyecek düzeyde ilişki olduğu görülmektedir. Bundan dolayı $\mathrm{H} 2 \mathrm{~K}$ hipotezi reddedilmiştir.

H2L: İşletmelerdeki kurumsallaşma düzeyi ile işletmedeki çalışanların işletmeye karşı hissettikleri aidiyetlik duygusu arasında anlamlı bir ilişki vardır. İşletmelerdeki kurumsallaşma düzeyi ile işletmedeki çalışanların işletmeye karşı hissettikleri aidiyetlik duygusu arasında (r: 0.258) zayıf düzeyde bir ilişki olduğu görülmektedir. Bundan dolayı H2L hipotezi kabul edilir.

H2M: İşletmelerdeki kurumsallaşma düzeyi ile işletmedeki çalışanların karar alma süreçlerine katılımı arasında anlamlı bir ilişki vardır. İşletmelerdeki kurumsallaşma düzeyi ile işletmedeki çalışanların karar alma süreçlerine katılımı arasında (r: 0.174 ve p: 0.14) bir ilişki yoktur ya da önemsenmeyecek düzeyde ilişki olduğu görülmektedir. Bundan dolayı H2M hipotezi reddedilmiştir.

H2N: İşletmelerdeki kurumsallaşma düzeyi ile işletmedeki çalışanların yönetime olan güveni arasında anlamlı bir ilişki vardır. İşletmelerdeki kurumsallaşma düzeyi ile işletmedeki çalışanların yönetime olan güveni arasında (r: 0.298) zayıf düzeyde bir ilişki olduğu görülmektedir. Bundan dolayı H2N hipotezi kabul edilir.

H2O: İşletmelerdeki kurumsallaşma düzeyi ile işletmenin sosyal sorumluluk projelerine katkı sağlaması arasında anlamlı bir ilişki vardır. İşletmelerdeki kurumsallaşma düzeyi ile işletmenin sosyal sorumluluk projelerine katkı sağlaması arasında (r: 0.584) orta düzeyde bir ilişki olduğu görülmektedir. Bundan dolayı $\mathrm{H} 2 \mathrm{O}$ hipotezi kabul edilir.

H2P: İşletmelerdeki kurumsallaşma düzeyi ile işletmenin sosyal sorumluluk projelerinde ilimizin/ülkemizin tanıtımına katkı sağlaması arasında anlamlı bir ilişki vardır. İşletmelerdeki kurumsallaşma düzeyi ile işletmenin sosyal sorumluluk projelerinde ilimizin/ülkemizin tanıtımına katkı sağlaması arasında (r: 0.325 ) zayıf düzeyde bir ilişki olduğu görülmektedir. Bundan dolayı H2P hipotezi kabul edilir.

H2R: İşletmelerdeki kurumsallaşma düzeyi ile işletmenin uzun vadede toplumun refah düzeyini dikkate alması arasında anlamlı bir ilişki vardır. İşletmelerdeki kurumsallaşma düzeyi ile işletmenin uzun vadede toplumun refah düzeyini dikkate alması arasında (r: 0.176 ve p: 0.12 ) bir ilişki yoktur ya da önemsenmeyecek düzeyde ilişki olduğu görülmektedir. Bundan dolayı H2R hipotezi reddedilir.

H2S: İşletmelerdeki kurumsallaşma düzeyi ile işletmenin değişime öncülük etmesi arasında anlamlı bir ilişki vardır. İşletmelerdeki kurumsallaşma düzeyi ile işletmenin değişime öncülük etmesi arasında (r: 0.185 ve p: 0.15 ) bir ilişki yoktur ya da önemsenmeyecek düzeyde ilişki olduğu görülmektedir. Bundan dolayı H2S hipotezi reddedilir.

H2T: İşletmelerdeki kurumsallaşma düzeyi ile paydaşlarının gözünde işletmenin güvenilir bir imaja sahip olması arasında anlamlı bir ilişki vardır. İşletmelerdeki kurumsallaşma düzeyi ile paydaşlarının gözünde işletmenin güvenilir bir imaja sahip olması arasında (r: 0.274) zayıf düzeyde bir ilişki olduğu görülmektedir. Bundan dolayı $\mathrm{H} 2 \mathrm{~T}$ hipotezi kabul edilir.

Tablo 5'te ise işletmelerde kurumsallaşmaya yönelik ifadeleri ölçmeye yönelik olarak yapılan faktörlerin analizinin sonuçları paylaşılmıştır. 
Tablo 5. İşletmelerde Kurumsallaşmaya Yönelik Faktör Analizi

\begin{tabular}{|c|c|c|c|}
\hline Faktör & Faktör Alt Maddeleri & Faktör Yükü & Faktör Varyansı \\
\hline 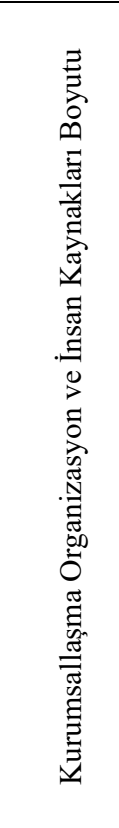 & $\begin{array}{l}\text { - İşletmede iş bölümü ve uzmanlaşmaya yönelik bir yapılanma söz } \\
\text { konusudur. } \\
\text {-İ̧̧letmede departmanlar arası bağımsızlık mevcuttur. } \\
\text { - Yönetime hazırlanan raporlar tecrübeler doğrultusunda elde } \\
\text { edilmektedir. } \\
\text { - İşletmemizde bütün personelin açıkça bilgilendirildiği yazılı } \\
\text { kurallar bulunmaktadır. } \\
\text {-İşletmede çalışanlar yeteneklerine göre terfi ettirilmektedir. } \\
\text {-Aile üyesi olmayan yöneticilerin yetki ve sorumlulukları kısıtlıdır. } \\
\text { - Çalışanlar yakın akrabalardan tercih edilmemektedir. } \\
\text {-İ̧letmede kayıtları tutanlar ile kontrolünü yapan kişiler farklıdır. } \\
\text { - İşletmede bütün sistemler birbirleri ile etkileşim halindedir. } \\
\text {-Yapılan işlerle ilgili iş akışs şemaları ve görev-yetki-sorumlulukları } \\
\text { belirten dokümanlar bulunmaktadır. }\end{array}$ & $\begin{array}{l}, 711 \\
, 668 \\
, 629 \\
, 619 \\
, 538 \\
, 522 \\
, 515 \\
, 508 \\
, 506\end{array}$ & 39,78 \\
\hline 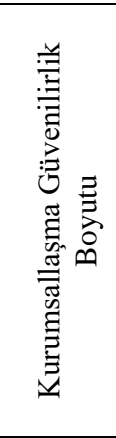 & $\begin{array}{l}\text { - Çalışanların işletmemize güçlü bir duygusal bağı vardır. } \\
\text { - İşletmemiz çalışanlarının yönetime olan güveni yüksektir. } \\
\text { - Çalışanlar işletme için her türlü özveriyi göstermektedirler. } \\
\text {-İşletmemizin hesap verebilirliği yüksektir. } \\
\text {-İşletmede güvenilirliğe önem verilmektedir. } \\
\text { - İşletmede çalışanlar işletmenin sorunlarına sahip çıkma konusunda } \\
\text { hassastır. }\end{array}$ & $\begin{array}{l}, 728 \\
, 717 \\
642 \\
629 \\
6616 \\
, 610\end{array}$ & 18,42 \\
\hline 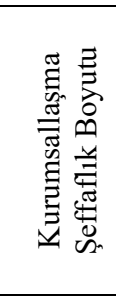 & $\begin{array}{l}\text { - İşletme yönetimi açıklığa ve şeffaflığa önem vermektedir. } \\
\text { - İşletme faaliyetlerimiz yönetsel açıdan son derece açık ve şeffaf } \\
\text { uygulamalara sahiptir. } \\
\text { - İşletmemiz ile ilgili bilgilere ilgililerin ulaşması mümkündür. } \\
\text { - İşletme içinde bilginin paylaşılması hızlıdır. }\end{array}$ & $\begin{array}{l}, 778 \\
754 \\
, 752 \\
, 628 \\
\end{array}$ & 11,34 \\
\hline \multicolumn{2}{|c|}{$\begin{array}{l}\text { KMO: 0,720 } \\
\text { Barlett's Test of Sphericity - Sig: } 0,000 \\
\text { Cronbach Alpha }=0,75\end{array}$} & \multicolumn{2}{|c|}{ Toplam Varyans: } \\
\hline
\end{tabular}

Yapılan faktör analizi sonucunda grupların soru dağılımları Tablo 5'de gösterilmektedir. Gruplar 3 faktöre ayrılmış ve sırasıyla; Kurumsallaşma Organizasyon ve İnsan Kaynakları Boyutu, Kurumsallaşma Güvenilirlik Boyutu ve Kurumsallaşma Şeffaflık Boyutu olarak belirlenmiştir. Kaiser- Meyer-Olkin (KMO) testinde hesaplanan değer 0,720'dır. Bu değer, faktör analizi yapmak için, veri setinin faktör analizine uygunluğunu, analizin geçerliliğini ve örneklemin büyüklüğünün yeterliliğini göstermektedir. Barletts testi değeri 0,05 'den küçük çıktığı için değişkenler arasında anlamlı bir ilişki olduğu Tablo 7' deki Sig: 0,000 değerinden anlaşılmaktadır. Yine Tablo 7 incelendiğinde toplam Cronbach Alpha Değerinin 0.75 olarak bulunduğundan bütün ifadelerin güvenilir ve kendi içinde tutarlı olduğu söylenebilir. Bu 3 faktör tüm yapıdaki değişimin (varyansın) yaklaşık yüzde 70'ini açıklamaktadır. KMO değeri yeterli olması veri setinin faktör analizine tabi tutulmak için yeterli sayıda olduğunun göstergesidir.

Kurumsallaşmanın organizasyon ve insan kaynakları boyutu, işletmede iş bölümü ve uzmanlaşmaya yönelik bir yapılanmanın olduğu, işletmede departmanlar arası bağımsızlığın mevcut olduğu, yönetime hazırlanan raporların tecrübeler doğrultusunda elde edildiği, işletmelerde bütün personelin açıç̧a bilgilendirildiği yazılı kuralların bulunduğu, işletmelerde çalışanların yeteneklerine göre terfi ettirildiği, aile 
üyesi olmayan yöneticilerin yetki ve sorumlulukları kısıtlı olduğu, çalı̧̧anların yakın akrabalardan tercih edilmediği, işletmelerde kayıtları tutanlar ile kontrolünü yapan kişiler farklı olduğu, işletmedeki bütün sistemlerin birbirleri ile etkileşim halinde olduğu, yapılan işlerle ilgili iş akış şemaları ve görev-yetkisorumlulukları belirten dokümanların bulunduğu ifadelerinden oluşmaktadır. Kurumsallaşmanın güvenilirlik boyutu; çalışanların işletmeye güçlü bir duygusal bağ ile bağlı olduğu, çalışanların yönetime olan güveninin yüksek olduğu ve işletme için her türlü özveriyi gösterdikleri, işletmelerin hesap verebilirliğinin yüksek olduğu, işletmelerde güvenilirliğe önem verildiği ve çalışanların işletmenin sorunlarına sahip çıkma konusunda hassas olduğu ifadelerinden oluşmaktadır. Kurumsallaşmanın şeffaflık boyutunda ise; işletme yönetiminin açıklığa ve şeffaflığa önem verdiği, işletme faaliyetlerinin yönetsel açıdan son derece açık ve şeffaf uygulamalara sahip olduğu, işletme ile ilgili bilgilere ilgililerin ulaşmasının mümkün olduğu ve işletme içinde bilginin paylaşılmasının hızlı olduğu ifadeleri yer almaktadır.

Tablo 6.'da "H3: İşletmelerde kurumsallaşma düzeyi ile işletmelerdeki etkin denetim arasında anlamlı biri ilişki vardır." hipotezine ilişkin test sonuçları sunulmuştur.

\section{Tablo 6. İşletmelerde Kurumsallaşma ve Etkin Denetim Düzeyi}

\begin{tabular}{|c|c|c|c|c|}
\hline \multicolumn{5}{|c|}{ İşletmede kurumsallaşma ile Denetim ilişkisi } \\
\hline $\begin{array}{l}\text { Kurumsallaşma Düzeyi ile Etkin } \\
\text { Denetim İlişkisi }\end{array}$ & $\begin{array}{c}\text { ETKİN } \\
\text { DENETIM } \\
\% \\
\end{array}$ & $\begin{array}{c}\text { ETKİN } \\
\text { OLMAYAN } \\
\text { DENETIM \% }\end{array}$ & $\begin{array}{l}\text { TOPLAM } \\
\%\end{array}$ & $\mathbf{P}($ sig. $)$ \\
\hline Kurumsal İşletme & 81 & 19 & 100 & $0,000 * *$ \\
\hline Kurumsallaşmamış İşletme & 48 & 52 & 100 & $0,000 * *$ \\
\hline \multicolumn{5}{|c|}{ Korelasyon Katsay1s1 r: 0,696 } \\
\hline \multicolumn{5}{|c|}{ İşletmede Muhasebe Bilgi Sisteminin Etkinliği İle Denetim Düzeyi İlişkisi } \\
\hline $\begin{array}{l}\text { Kurumsallaşma Düzeyi ile Etkin } \\
\text { Denetim İlişkisi }\end{array}$ & $\begin{array}{c}\text { ETKİN } \\
\text { DENETIM } \\
\%\end{array}$ & $\begin{array}{c}\text { ETKİN } \\
\text { OLMAYAN } \\
\text { DENETIM \% }\end{array}$ & $\begin{array}{l}\text { TOPLAM } \\
\%\end{array}$ & $\mathbf{P}($ sig. $)$ \\
\hline MBS Etkin & 72 & 28 & 100 & $0,000 * *$ \\
\hline MBS Etkin Değil & 31 & 69 & 100 & $0,000 * *$ \\
\hline \multicolumn{5}{|c|}{$\begin{array}{lll}\text { Korelasyon Katsayıs1 } r: 0,613 & \mathrm{P}(\operatorname{sig}) .0,000 \\
\end{array}$} \\
\hline \multicolumn{5}{|c|}{ İşletme Demografik Özellikleri ile İşletmenin Denetimi İlişkisi } \\
\hline İşletmelerin Demografik Özellikleri & $\begin{array}{l}\text { Ki-Kare } \\
\quad\left(x^{2}\right)\end{array}$ & df & $\begin{array}{l}\text { Korelasyon } \\
\text { Katsayısı (r) }\end{array}$ & $\mathbf{P}($ sig. $)$ \\
\hline İşletmenin Büyüklüğü (Çalışan sayısı) & 23,68 & 6 & 0,587 & $0,000 * *$ \\
\hline İşletmenin Faaliyet Süreleri & 27,45 & 12 & 0,497 & $0,000 * *$ \\
\hline İşletmenin Tüzel Kişiliği & 45,21 & 33 & 0,539 & $0,001 * *$ \\
\hline İşletmenin Faaliyet Sektörü & 41,13 & 47 & 0,167 & 0,262 \\
\hline Yöneticilerin Sektör Tecrübeleri & 22,14 & 47 & 0,177 & 0,138 \\
\hline Yöneticilerin Eğitim Durumları & 31,37 & 12 & 0,196 & 0,116 \\
\hline
\end{tabular}

H3: İşletmelerde kurumsallaşma düzeyi ile işletmelerdeki etkin denetim arasında anlamlı biri ilişki vardır. Kurumsallaşma düzeyi ile etkin denetim arasında r:696 olduğundan kuvvetli değerlendirilebilecek düzeyde anlamlı bir ilişki bulunmaktadır. Bundan dolayı H3 kabul edilir. Kurumsallaşmanın olmazsa olmaz ölçütlerinden biri işletmenin açık, şeffaf ve hesap verebilir olmasıdır. Bu nedenle de kurumsallaşma ve denetim birbirinden ayrı düşünülememektedir.

H3A: İ̧̧letmelerde MBS'nin etkin kullanılması ile işletmelerdeki denetim arasında anlamlı biri ilişki vardır. MBS'nin etkin kullanılması ile işletmelerdeki denetim arasında ise r:0,613 olduğundan kuvvetli değerlendirilebilecek düzeyde anlamlı bir ilişki bulunmaktadır. Bundan dolayı H3A kabul edilir.Denetim için irdelenen tablolar ve finansal verilerin muhasebe bilgi sisteminden sağlandığından denetimin etkinliği için MBS'nin etkin kullanımı büyük öneme sahiptir.

H3B: İşletmelerin büyüklüğü (çalışan sayısı) ile işletmelerin etkin denetimi arasında anlamlı bir ilişki vardır. İşletmenin büyüklüğü ile denetim faaliyetleri arasındaki ilişkilere bakıldığında işletmenin büyüklüğü, 
faaliyet süresi ve tüzel kişiliği ile denetim arasında orta düzeyde anlamlı bir ilişki bulunurken yöneticilerin sektör tecrübeleri ve eğitim düzeyleri ile denetimin etkinliği arasında anlamlı bir ilişki bulunmamaktadır. İşletmelerin büyüklüğü (çalışan sayısı) ile işletmelerin etkin denetimi arasında (r: 0.587) orta düzeyde bir ilişki olduğu görülmektedir. Bundan dolayı H3B hipotezi kabul edilir.

H3C: İşletmelerin faaliyet süreleri ile işletmelerin etkin denetimleri arasında anlamlı bir ilişki vardır. İşletmelerin faaliyet süreleri ile işletmelerin etkin denetimleri arasında (r: 0.497) orta düzeyde bir ilişki olduğu görülmektedir. Bundan dolayı $\mathrm{H} 3 \mathrm{C}$ hipotezi kabul edilir.

H3D: İşletmelerin tüzel kişilikleri ile işletmenin etkin denetimi arasında anlamlı bir ilişki vardır. İşletmelerin tüzel kişilikleri ile işletmenin etkin denetimi arasında (r: 0.539) orta düzeyde bir ilişki olduğu görülmektedir. Bundan dolayı H3D hipotezi kabul edilir.

H3E: İşletmelerin faaliyet sektörleri ile işletmelerin denetimi arasında anlamlı bir ilişki vardır. İşletmelerin faaliyet sektörleri ile işletmelerin denetimi arasında ( $\mathrm{r}: 0.167$ ve p: 0.262 ) bir ilişki yoktur ya da önemsenmeyecek düzeyde ilişki olduğu görülmektedir. Bundan dolayı H3E hipotezi reddedilir.

H3F: İşletmelerin yöneticilerinin sektör tecrübeleri ile işletmenin denetimi arasında anlamlı bir ilişki vardır. İşletmelerin yöneticilerinin sektör tecrübeleri ile işletmenin denetimi arasında (r: 0.177 ve p: 0.138) bir ilişki yoktur ya da önemsenmeyecek düzeyde ilişki olduğu görülmektedir. Bundan dolayı H3F hipotezi reddedilir.

H3G: İşletmelerin yöneticilerin eğitim düzeyleri ile işletmelerin denetimi arasında anlamlı bir ilişsi vardır.Işsletmelerin yöneticilerinin eğitim düzeyleri ile işletmelerin denetimi arasında (r: 0.196 ve p: 0.116) bir ilişki yoktur ya da önemsenmeyecek düzeyde ilişki olduğu görülmektedir. Bundan dolayı H3G hipotezi reddedilir.

\section{SONUÇ VE DEĞERLENDİRME}

Gelişen teknoloji işletme süreçlerini kolaylaştırmakla beraber işletmelerin sürdürülebilirliklerini sağlamalarının temel koşulu olan rekabet ortamında başarıyı her geçen gün daha da zor ulaşılabilir bir hedef haline getirmektedir. Geçmişte başarı sadece daha yüksek kâr elde edebilmek olarak algilanmakta ve çoğu zaman kaliteden ödün vererek maliyetleri azaltarak veya fiyatları yükselterek bu hedeflere ulaşılabilmekteydi. Ancak bu anlayış günümüzde yerini kaynakların etkin kullanımı ve firma imajının artırılmasına bırakmıştır. Sosyal sorumluluk anlayışının yerleştiği, adil, şeffaf ve hesap verebilir kurumsal yönetim felsefesinin hâkim olduğu işletmeler, üretimden pazarlamaya, insan kaynaklarından halkla ilişkilere ve finans bölümüne kadar tüm bölümlerde yerleşik süreçleri farklılaştırmak zorunda kalmıştır. Bu değişimin gerçekleşebilmesi için ise etkin bir bilgi yönetim mekanizması gerekmektedir. İlgili mekanizma ise muhasebe fonksiyonuna bakış açısının değişimi ile mümkündür. Çünkü Muhasebe bilgi sistemi, işletme ile ilgili tüm paydaşların etkin kararlar alabilmesine yardımcı olacak değerli veriler üretmektedir ve aynı zamanda kurumsallaşma sürecinin yapı taşlarındandır.

Bilgi günümüzde önceki dönemlere göre çok daha hızlı ulaş1labilir, ihtiyaca göre biçimlendirilebilir ve amaca uygun kullanılabilir durumdadır. Bu durum avantaj olduğu gibi dezavantaj da olabilmektedir. Çünkü, işletmeler için hayati önem arz eden bilginin güvenliği de yeni bir risk unsuru olarak ortaya çıkmaktadır. Bu risk, bilgi güvenliğinin sağlanması için ilave maliyetlere yol açmakla birlikte, etkin bir bilgi sisteminin sağlayacağı faydalar düşünüldüğünde katlanılabilir düzeyde kalacaktır.

Özellikle yöneticiler için günümüz yaşam koşullarında en değerli kaynak zamandır. Yöneticilerin değerlendirebileceği bilginin sınırsız olduğu düşünülürse yöneticiler için önemli olan doğru ve gerekli miktarda bilgiye doğru zamanda ulaşabilmektir. Bunu sağlayan sistem ise bilgi sistemleridir. Bilgi sistemleri veri ve bilgi kalabalığı yerine amaca uygun bilgi oluşturarak hem kafa karışıklığını önler hem de zaman kaybı yaşanmasına engel olur. Ayrıca hem geçmişe dönük bir arşiv işlevi görür hem de anlık durum yansıtmalarına yarar.

Zamanın etkili kullanılmasını sağlamasının yanında bilgi sistemleri doğru kararlar alınmasına da olanak sağlar. İşletmeler içinde faaliyet gösterdikleri dış çevreden bağımsız düşünülemezler ve yöneticilerin öncelikli amaçlarından biri diğer bir deyişle yöneticiyi farklı ve özel kılan en önemli özelliklerden biri de belirsiz dış çevre koşullarını öngörebilmesi, doğru değerlendirebilmesidir. Karanlık içinde yönünü tayin etmeye çalışan bir kaptan olan yöneticiler için bilgi sistemleri yönetim kararlarının alınmasında 1şık görevi gören fenerlerdir. Ancak feneri doğru kullanmak ve yönünü doğru tayin etmek günümüz koşullarında yine insani yetiler gerektirir.Yani insan faktörünün önemi ve yöneticilerin bireysel yetenekleri hala önemini korumakla birlikte, bilgi sistemlerini doğru kullanabilmekte yöneticilerde olması gereken özelliklerin içinde değerlendirebilir. İşletmeler için önemi açıkça görülebilen bu kaynaklar genelde bilgi sistemleri olarak düşünülürken özelde 
işletmenin her departmanında ihtiyaç duyulan veya üretilebilen bilgiler farklıdır. Bu açıdan bilgi sistemleri de çeşitlidir. Üretim bilgi sistemi, insan kaynakları bilgi sistemi, pazarlama bilgi sistemi, finansal bilgi sistemi ve muhasebe bilgi sistemi farklı verilere ihtiyaç duyan ve farklı bilgiler üreten sistemler olarak işletmelerde yer almaktadır. Ancak tüm bu sistemlerin içinde muhasebe bilgi sistemi tüm sistemlerle etkileşim halinde olan bir sistem olarak diğerlerinden ayrılmaktadır.

Muhasebe bilgi sistemi diğer sistemlere veriler üreten bununla birlikte diğer sistemlerce üretilen verileri de işleyip bilgilere dönüştüren bir sistemdir. Bunun yanı sıra diğer sistemler yalnızca iç kullanıcılara bilgi üretirken muhasebe bilgi sistemince üretilen bilgiler tüm işletme ilgililerine karar süreçlerinde dayanak oluşturacak tabloları da sağlar. Ayrıca işletme yönetiminin önünü görmesini bulunduğu noktayı anlamasını sağlarken bu bilgiler ışığında karar almalarına da yardımcı olur.

Yönetimin birçok kaynakta karar alma becerisi olarak tanımlanması yönetimde karar almanın rolü ve önemini ortaya koymaktadır. Doğru kararlar almak doğru zamanlamalar yapmak işletmeler için yaşamsal önem taşır. Koşullar değiştikçe yönetim anlayışları da değişmekte rekabet işletmeleri kurumsallaşmaya zorlamaktadir.

Sistemi bireylerden bağımsız hale getirmek işletmeler için önemli bir amaçtır. Bunun yolu da işletmenin iş akışlarının prosedürlerinin kurallarının belirli olduğu, çalışanların işletmeye güven ve beraberinde bağl1lık duyduğu bir yapı kurmasıyla yani kurumsallaşmasıyla mümkündür. Yine işletmelerin içinde var oldukları dış çevreye de duyarlı olmaları işletmenin itibarını artıran en önemli konulardan biridir. Şeffaf ve açık bir yönetim anlayışı; eşit ve adil bir yönetim ve bulunduğu çevreyi önemseyen duyarlı yani sosyal sorumluluğu olan işletmeler fark yaratabilen ve ayakta kalabilen işletmeler olarak rekabet edebilme yeteneklerini artırabilirler. Ancak şeffaf ve açık olmayı amaçlayıp bunun için çabalamak önemli bir iyi niyet olsa da yalnızca sözde ya da ifadede olması bir anlam içermez. Önemli olan bunu ete kemiğe büründürmek bu iddiayı gerçekleştiren bir irade ortaya koymaktır. Bunun ölçütü ise bir anlamda denetimdir. Denetim işletmeler için olmazsa olmaz olarak görülebilecek değerlendirmeler bütünüdür. İşletmenin mevcut durumunu anlamak ve daha ileriye taşımak için denetim önemli bir anahtardır.

Kurumsallaşma ve denetim kavramlarını birbirinden ayrı düşünmek mümkün değildir ve bu anlamda iddiası olan işletmeler için muhasebe bilgi sistemi olmazsa olmazdır. Denetime dayanak olacak bilgilerin sağlanması, kurumsal bir yapının gerektirdiği yönetim kararlarının alınması için bilgi ilk ve en önemli şart, bunu sağlayacak sistem olan muhasebe bilgi sistemi ise vazgeçilemeyecek bir araçtır.

$\mathrm{Bu}$ bilgiler 1şı̆̆ında Karaman OSB'de faaliyet gösteren işletmeler üzerinde bir araştırma yapılmıştır. Karaman OSB ülkemiz ekonomisi içinde özellikle ihracat rakamlarıyla önemli bir yere sahipken, Karaman'ın gelişmesine büyük katkıları olan, Orta Anadolu'nun önemli bir istihdam merkezi olma özelliğine de sahiptir. $\mathrm{Bu}$ anlamıyla bu çalışma hem ülkemiz hem Orta Anadolu Bölgesi hem de Karaman için büyük öneme sahip olan işletmelerde yapılmış, muhasebe bilgi sisteminin etkinliğini ortaya koyarken, kurumsallaşma ve denetimin muhasebe bilgi sistemiyle ve birbirleriyle olan ilişkilerini de ortaya koymayı amaçlamıştır. Anket soruları yalnızca yönetici ve sahip/ortak konumunda bulunan kişilere yöneltilmiştir. Bu yanıyla çalışma sonuçları işletme yöneticilerinin genel profili ile ilgili de fikir oluşturulmasına olanak sağlamıştır. Anket formu muhasebe bilgi sisteminin etkinliğini ölçmeyi amaçlayan, kurumsallaşma düzeyini anlamayı amaçlayan ve denetim faaliyetleri ile ilgili bilgileri içeren sorulardan oluşmaktadır. Yapılan analizlerle birbirleriyle ilişkileri olup olmadığı ya da ne derece önemli ilişkiye sahip oldukları anlaşılmak istenmiştir.

Muhasebe bilgi sisteminin işletmelere sağlayacağı faydalar ve etkinliğinin sağlanması ile ilgili pek çok çalışmanın yapıldığı yapılan literatür taramasında görülmüş ve bunun kurumsallaşma ile ilişkisinin değerlendirilmesini içeren bir çalışma yaparak konuya farklı bir bakış açısı getirilmek istenmiştir. Muhasebe bilgi sisteminin yalnızca muhasebe bölümü sınırlı olup olmadığı veya yalnızca vergisel yükümlülükleri yerine getirebilmek amacıyla takip edilip edilmediğinin incelenmesi amaçlanmıştır. Bunun yanı sıra yönetimin karar süreçlerinde önemli bir kaynak olarak değerlendirilebilecek en önemli sistem olmasına rağmen yöneticiler tarafından bu farkındalığın mevcudiyetinin varlığını anlamak amacına da hizmet eden bu çalışmada denetim faaliyetlerine de yer verilmiştir. Bunun nedeni kurumsallaşmanın sağlanmasında denetim faaliyetlerinin önemli rol oynamasıdır. Çünkü denetim faaliyetleri muhasebe bilgi sisteminin işlevselliğini ve buradan üretilen bilgilerin kalitesini artırmakta, kurumsallaşmanın en önemli amaçları olan, Sosyal Sorumluluk, Şeffaflık, Hesap Verebilirlik ve Adillik amaçlarına ulaşmada stratejik bir araçtır.

Yöneticiler işletme ile ilgili pek çok karar almak zorundadır. Farklı bölümleri ilgilendiren farklı kararların alınma süreçlerinde muhasebe bilgi sisteminden yararlanma düzeyleri de bu çalışmada yer verilen diğer konulardandır. Ayrıca Kayıt, Raporlama, Bilgilendirme ve Değerlendirme İşlevlerinde MBS'nin Önem Düzeyini anlamaya yönelik sorulara da yer verilerek muhasebe bilgi sisteminin işletme içi bilgi akışını sağlaması işlevine de değinilmiştir. 


\section{Çalışmanın sonuçları değerlendirildiğinde;}

Ağırlıklı olarak gıda sektöründen katılımcı olduğu bunu ambalaj sektörünün izlediği görülmektedir. Çalışmaya katılanların \%49 'u gida sektöründe \%27'si ise ambalaj sektöründe faaliyet gösteren işletmelerdir. $\mathrm{Bu}$ durum Karaman OSB'nin genel bir yansıması olarak görülebilir. Gıda sektörünün ağırlıkta olduğu bölgelerde ambalaj sektörünün gelişmesi de beklenen bir sonuç olarak değerlendirilebilir.

Yapılan ki-kare analizleri ile İşletmenin faaliyet gösterdiği sektör ile muhasebe bilgi sisteminin etkinliği arasında anlamlı ilişki olduğu (r:0,226 ) ancak denetim ve kurumsallaşma ile sektör arasında anlamlı bir ilişki olmadığg görülürken işletmenin büyüklüğü ile muhasebe bilgi sisteminin etkinliği arasında orta düzeyde (r:0,514), kurumsallaşma ve işletme büyüklüğü arasında (r: 0.611) kuvvetli ve denetim ile işletme büyüklüğü arasında (r: 0.587) arasında orta düzeyde anlamlı ilişki olduğu ortaya çıkmıştır.

Muhasebe bilgi sisteminden işletme kararlarında yararlanma düzeyleri incelendiğinde özellikle finansman kararlarında, maliyetleri azaltmada, tedarikçilerin tespitinde oldukça yüksek bir yararlanma düzeyinin olduğu bunun yanı sıra tüm işletme kararlarında muhasebe bilgi sisteminden yararlanıldığı görülmektedir. Ki kare değerine ilişkin anlamlılık düzeyi değerlendirildiğinde tüm kararlar ile MBS'nin etkin kullanımı arasında $(\mathrm{p}=0,000)$ anlamlı bir ilişki olduğu görülmektedir. Bu sonuçlardan yola çıkarak MBS'nin karar alma süreçlerinde kullanılması ile ilgili Karaman OSB'de faaliyet gösteren işletmelerin yöneticilerinde bir farkındalık olduğu düşünülmektedir.

Sonuçlar incelendiğinde dikkat çeken bir diğer nokta Kayıt, Raporlama, Bilgilendirme ve Değerlendirme İşlevlerinde MBS'nin Önem Düzeyine ilişkin ortaya çıkan sonuçlardır. Bu anlamda muhasebe bilgi sistemi işletmenin geçmişe dönük hafızası olmasının yanında bugüne dair özeti hatta anlık fotoğrafı olarak görülmektedir. Verilen cevaplar değerlendirildiğinde tüm sorulara verilen cevapların ortalamalarının 3 ve üzeri olması MBS'nin sadece vergilendirme amacıyla tutulan kayıtlar değil işletmede ihtiyaç duyulan bilgilerin kaynağı finansal performansın ölçülmesini sağlayan bilgileri üreten sistem ve işletme içinde koordinasyon işlevini de yerine getiren bir sistem olarak değerlendirildiği görülmektedir. Bu noktadan hareketle Karaman OSB'de bulunan firmalarda muhasebe bilgi sisteminin kullanıldığı, karar süreçlerinde etkili olduğu, kayıt raporlama bilgilendirme ve değerlendirme süreçlerinde muhasebe bilgi sisteminden yararlanıldı̆̆ görülmektedir. $\mathrm{Bu}$ işletmelerin kurumsallaşma hedefine sahip oldukları bu anlamda açıklık ve şeffaflık ilkelerine, iş bölümü ve uzmanlaşmaya, prosedürlere, sosyal sorumluluklara önem verildiği görülmekte ancak Ki-kare analizine göre kurumsallaşma ve çalışanların yönetime katımı arasında (r: 0.174) olduğundan anlamlı bir ilişki görülmediğinden çalışanların yönetimi katılımının artırılması gerektiği düşünülmektedir.

Araştırma sonuçları genel olarak ele alındığında işletmelerin muhasebe bilgi sisteminin öneminin farkında olduğu, sistemlerin etkin kullanılması için eğitim çalışmaları yaptığı ve karar alma süreçlerinde MBS den yararlanıldığı görülmekte, Kurumsallaşma ve denetim ile muhasebe bilgi sisteminin etkinliği arasında anlamlı ilişki olduğu ortaya çıkmaktadır. Kurumsallaşma ile muhasebe bilgi sistemi ilişkisi incelendiğinde ortaya çıkan sonuç kurumsallaşma düzeyi ile muhasebe bilgi sisteminin etkinliği arasında (r: 0.712) anlamlı bir ilişki bulunduğu şeklindedir. Kurumsallaşma denetim ilişkisi incelendiğinde ise kurumsal işletmelerde denetimin etkin olduğu (r:696) görülmektedir. Muhasebe bilgi sisteminin etkinliği ile denetimin etkinliği arasındaki ilişki incelendiğinde (r:0,613) olduğundan kuvvetli derecede anlamlı bir ilişkinin olduğu görülmektedir.

Çalışma ile ilgili bir değerlendirme yapıldığında rekabet etmenin işletmeler için her geçen gün daha zorlaştığı, bu ortamda ayakta kalmak isteyen işletmelerin doğru yönetilmeleri gerektiği, bunun da ancak doğru kararlar ile başarılabileceğine çalışmada sıkça değinilmiştir. Doğru kararlar alabilmek için bilgiye ihtiyaç duyulduğu, bu bilginin ancak bilgi sistemlerinden sağlanabileceği ve tüm bilgi sistemlerinin de bir biçimde muhasebe bilgi sistemiyle ilişkili olduğu ortaya konulmuştur. $\mathrm{Bu}$ anlamda muhasebe bilgi sisteminin etkinliğinin sağlanmasının işletme için ne derece önemli olduğu belirtilmiştir. İşletmelerin başarıya ulaşmaları için kurumsallaşmalarının zorunlu hale geldiği bir çağda olduğumuz bilinirken işletmeler büyüdükçe kurumsallaşmanın ve bilgi sistemlerinin etkinliğinin öneminin de arttığı görülmüsstür. Denetim ve kurumsallaşmanın birbirinden ayrı düşünülemeyeceği ve muhasebe bilgi sisteminin bu süreçlerdeki önemli rolüne de çalışmada değinilmiştir.

Çalışmada ele alınamayan konulara gelince Araştırmanın Karaman OSB ile sınırlı tutulması muhasebe bilgi sisteminin etkinliğinin yalnızca üretim işletmelerinde ölçülmesine neden olmuştur. Hizmet üreten işletmelerde muhasebe bilgi sistemi, kurumsallaşma ve denetimin ilişkisine bu çalışmada değinilmemiştir. Ayrıca bu çalışmada etkin bir yönetimde bilginin ve bilgi sistemlerinin önemine çokça değinilmesine karşın günümüz işletmeleri için oldukça önemli olan bilgi güvenliği konusu detaylıca irdelenmemiş, bilgi güvenliği ile ilgili bir araştırma yapılmamıştır. Yine çalı̧̧mamızda bilgi sistemlerinin ürettiği bilgiden nasıl yararlanılacağı ya da muhasebe bilgi sisteminden elde edilen tabloların yorumlanması ile ilgili bir bölüm de bulunmamaktadır bu 
yanıyla çalışma daha çok kurumsallaşma ve muhasebe bilgi sistemi ilişkisini anlamaya yönelik olarak değerlendirilmelidir.

Günümüz gelişen teknolojisinde bilgi sistemlerinin kullanımı yalnızca kar amacı güden işletmelerle sınırlı değildir. Kar amacı gütmeyen kuruluşlarda da hatta kamu kurum ve kuruluşlarında da bilgi sistemlerinin önemi giderek artmaktadır. Kamu kurum ve kuruluşlarında bilgi sistemlerinin kullanımı ile ilgili de çalışmalar yapilabilir.

Bilgi sistemlerinin ne derece istenilen düzeyde olduğu ve geliştirilmesi için yapılabilecekler de bu alanda yapılacak faklı bir çalışmanın konusu olabilir. Yine değişim yönetimi ve bilgi sistemleri konusu bu çalışmada ele alınamamış olsa da bir başka çalışmada detaylandırılması mümkündür.

Son olarak değinilmek istenen birkaç önemli nokta daha bulunmaktadır. Teknolojinin giderek daha da önemli hale geldiği bilinse de şu an bulunulan nokta da bilgiyi her ne kadar sistemler üretiyor olsa da sistemi kullanan daha da önemlisi anlayan ve yorumlayan halen insan faktörüdür. Bu yanıyla sistemlerin kullanılması için eğitimlere önem verilmesi hem sistemlerden maksimum yararı sağlamaya yarayacak hem de zamanı etkili ve verimli kullanırken risklerden de mümkün olduğunca kaçınılmasına olanak sağlayacaktır. Ayrıca işletmenin başarısı için, karar verici konumda bulunan ya da bulunmayı hedefleyen tüm iş görenlerin sistemlerin kullanımına hakim olmaları ve kendilerini bilgiyi yorumlayabilecek biçimde donatmaları en az bilgi sistemlerinin etkinliği kadar önemlidir.

Değişimin kaçınılmaz olduğu bu dönemde teknolojiye direnmek yerine teknolojiyle yönetmek yöneticiler için fark yaratacak, işletmeleri de hedeflerine ulaştıracaktır. Bunun için işletmelerin daha kuruluş aşamasından kurumsallaşma hedeflerinin olması işletme yapısını buna göre kurmaları ve bilgi sistemlerine sonradan entegre olmak yerine baştan sahip olmalarının avantaj sağlayacağı düşünülmektedir. Yine insan kaynağının yetiştiği tüm kurumlarda pratiğe yönelik eğitimlere de yer verilmesi kısaca sistem kullanıcılarının donatımlı hale gelmesi önemliyken, bu sistemleri üretebilmeyi hedefleyen bir bakış açısına da sahip olmanın önemli olduğu düşünülmektedir.

Sonuç olarak bu çalışmada muhasebe bilgi sisteminin yönetimin kullanabileceği önemli bir yönetim aracı olduğu ortaya konmuş ve yapılan uygulama çalışmasında da Karaman OSB'de faaliyet gösteren firmalarda bu anlamda bir farkındalığın olduğu işletmeyi ilgilendiren, işletmeyi ileri götürecek tüm kararlarda muhasebe bilgi sisteminden yararlanıldığı görülmüştür. Ayrıca kurumsallaşma, denetim ve muhasebe bilgi sisteminden yararlanılması arasında anlamlı bir ilişkinin olduğunun görülmesi muhasebenin kayıt tutmak ve vergilendirmenin doğru yapılmasını sağlamak gibi işlevlerinin yanında yönetimin etkinliğini sağlama ve örgütsel başarıya ulaştırma işlevlerinin de olduğunu ortaya çıkarmıştır. Bu anlamıyla yönetim ve liderlik bütüncül bir yaklaşımla, bilgi sistemlerinin kullanılmasıyla ve muhakkak ki insan faktörünün öneminin her zaman farkında olmasıyla başarıya ulaşabilecektir. $\mathrm{Bu}$ yüzden teknolojiyi reddetmeden teknolojiden yararlanarak aynı zamanda adil, insana değer veren ve katılımeı bir yönetim anlayışıyla yönetildiği zaman işletmelerin başarıya ulaşılabileceği unutulmamalıdır. 


\section{KAYNAKÇA}

Acar, Durmuş ve Vesile Ömürbek, (2003). "Bilgi Teknolojilerinin Muhasebe Bilgi Sistemi Kullanımı Üzerine Etkisi ve Bir Uygulama: Gıda Sektörü", Muhasebe ve Finansman Dergisi, Sayı:20,Ekim 2003, s. 66 - 78.

Akar, Ezgi (2016). "İşletmelerde Muhasebe Bilgi Sisteminin Etkinliğinin Değerlendirilmesi Üzerine Çanakkale İlinde Bir Araştırma", Yüksek Lisans Tezi ,Çanakkale 18 Mart Üniversitesi, Sosyal Bilimler Enstitüsü, Çanakkale.

Akgün, Ali İhsan ve Selçuk Kılıç, (2013). "Muhasebe Bilgi Sisteminin İşletme Yönetiminin Etkinliği Üzerindeki Etkisi", Yönetim ve Ekonomi: Celal Bayar Üniversitesi İktisadi ve İdari Bilimler Fakültesi Dergisi , 20 (2) , 21-36

Aktaş, Ramazan, (2017). Kurumsal Yönetim (12. Bölüm). Sakarya: Sakarya Üniversitesi Sürekli Eğitim Uyg. Arş. Mer. Yayınları.

Alp, Ali ve Kılıç, Saim (2014). Kurumsal Yönetim Nasıl Yönetilmeli?. İstanbul: Doğan Kitabevi.

Aydemir, Burhan ve diğ., (2004). "Aile İşletmelerinde Kurumsallaşma Süreci ve Sektörel Bir Uygulama", Aile İşletmeleri Kongresi Kongre Kitabı Nisan 17 - 18 2004, İstanbul: İstanbul Kültür Üniv. Yayınları, s. 604 - 617.

Başok Yurdakul, Nilay, (2008). Farklılaşma Çağında Kurumsal Başarıyı Yakalamak, Nobel Yayınları, Ankara.

Çidem, İbrahim (2013). "Muhasebe Bilgi Sisteminin Etkinliği: Küçük ve Orta Büyüklükte İşletmeler Üzerine Bir Araştırma", Yüksek Lisans Tezi Erciyes Üniversitesi, Sosyal Bilimler Enstitüsü, Kayseri.

Dalgın, Burcu, (2008). "Muhasebe Bilgilerinin Karar Almada Kullanımının Önemi ve Çanakkale Sanayi İşletmelerinde Bir Uygulama", Yüksek Lisans Tezi, Çanakkale 18 Mart Üniversitesi, Sosyal Bilimler Enstitüsü, Çanakkale.

Dızman, Şakir ve Güney, Selami , (2015). Muhasebe ve Muhasebecilerin Yönetim Kararları Üzerine Etkisi,Ekin Yayınları, Bursa.

Dinç, Engin ve Hasan Abdioğlu, (2009). "İşletmelerde Kurumsal Yönetim Anlayışı ve Muhasebe Bilgi Sistemi İlişkisi: İMKB-100 Şirketleri Üzerine Ampirik Bir Araştırma", Balıkesir Üniversitesi Sosyal Bilimler Enstitüsü Dergisi , $12(21), 157-184$.

Eminoğlu, Cafer (2014). Türk Ticaret Kanunu'nda Kurumsal Yönetim. İstanbul: XII Levha Yayınları.

Erdil, Oya ve diğ., (2002). "Çevresel Belirsizliğin Düşük ve Yüksek Olduğu Ortamlarda Tedarikçi Performansının Satın Alma Davranışına Etkisi", Gaziantep Üniversitesi, Sosyal Bilimler Enstitüsü, Sosyal Bilimler Dergisi, Cilt:5,Sayı:1, s. 193 - 206

Kaderli, Yusuf ve Köroğlu, Çağrı (2014)." İşletmelerde Muhasebe Bilgi Sistemi ile Kurumsal Yönetim Anlayışı Arasındaki İlişki", Mufad Journal,Temmuz 2014, Sayı:63, s. 21 - 37.

Kalmış, Halis ve Burcu Dalgın, (2010). "Muhasebe Bilgilerinin Karar Almada Kullanımının Önemi Çanakkale'de Faaliyet Gösteren Sanayi İşletmelerinde Bir Uygulama", Mufad Journal, Nisan 2010, Sayı:46, 112 - 128.

Karpuzoğlu, Ebru, (2003). Büyüyen ve Gelişen Aile Şirketlerinde Kurumsallaşma, 2. bs.,Hayat Yayınları, İstanbul.

Ulukan, Cemil, (2005). "Türkiye'ye Özgü Kurumsallaşma Anlayışı ve Sonuçları", İktisat, İşletme ve Finans Dergisi, Bilgesel Yayıncilık, 20(231), s. 88-96 Y11 20, 89.

Varıcı, İdiris, (2007), "Muhasebe Bilgi Sisteminin Kurumsallaşma Üzerine Etkisi: Orta ve Doğu Karadeniz’deki KOBİ'ler Üzerine Bir Uygulama",Yüksek Lisans Tezi, Karadeniz Teknik Üniversitesi, Sosyal Bilimler Enstitüsü, Trabzon.

Yavuz, Hasan (2014). "Muhasebe Bilgi Sisteminin İşletme Yönetim Kararları Üzerinde Etkileri: Bartın İlindeki KOBİ’ler Üzerinde Bir Araştırma", Yüksek Lisans Tezi, Bartın Üniversitesi, Sosyal Bilimler Enstitüsü, Yüksek Lisans Tezi, Bartın.

Yozgat, Uğur, (1994). Yönetimde Karar Verme Teknikleri, Beta Yayınları, İstanbul. 